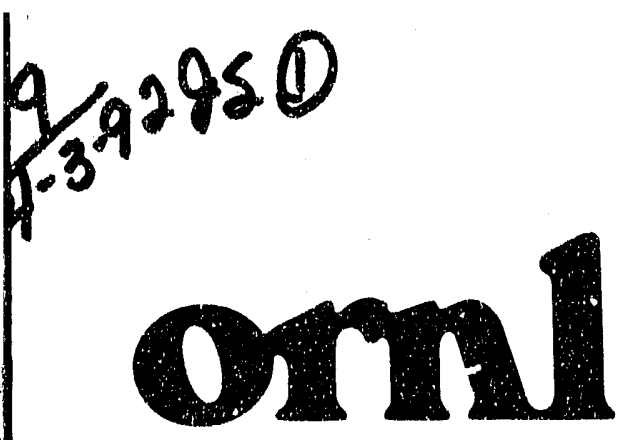

ORNL/M-1793

OAK RIDGE

NATIONAL

LABORATOPY

MAFTH MALIETRA

\title{
Active Sites Environmental Monitoring Program: Program Plan Rev. 1
}

T. L. Ashwood

D. S. Wickliff

C. M. Morrissey

Environmental Sciences Division

Publication No. 3799

MANAGED BY

MARTIN MARIETTA ENERGY SYSTEMS, INC.

FOR THE UNITED STATES

DEPARTMENT OF ENERGY 
This report has been reproduced directly from the best available copy.

Available to DOE and DOE contractors from the Office of Scientlic and Technical information, P.O. Box 62, Oak Ridge, TN 37B31; prices available from (615) 576-8401, FTS 626-8401

Available to the public from the National Teclinical Information Service, U.S. Department of Commerce, 5285 Port Royal Rd., Springtield, VA 22161.

This report was prepared as an account of work sponsored by an agency of the United States Government. Neither the United States Government nor any agency thereof, nor any of their employees, makes any warranty, express or implied, or assumes any legal liability or responsibility for the accuracy, completeness, or usefuiness of any information, apparatus, product, or process disclosed, or represents that its use would not infringe privately owned rights. Reference herein to any specific commercial product, process, or service by trade name, trademark, manufacturer, or otherwise, does not necessarily constitute or imply its endorsement, recommendation, or favoring by the United States Government or any agency thereof. The views and opinions of authors expressed herein do not necessarily state or reflect those of the United States Government or any agency thereof. 
Environmental Sciences Division

\section{ACTIVE SITES ENVIRONMENTAL MONITORING PROGRAM: PROGRAM PLAN \\ Rev. 1}

T. L. Ashwood, D. S. Wickliff, and C. M. Morrissey

Environmental Sciences Division Publication No. 3799

Manuscript Completed-December 1991

Date Published-February 1992

Prepared for

Office of Environmental Restoration and Waste Management

(EW 3010010)

Prepared by the

OAK RIDGE NATIONAL LABORATORY

Oak Ridge, Tennessee 37831-6285

managed by

MARTIN MARIETTA ENERGY SYSTEMS, INC.

for the

U.S. DEPARTMENT OF ENERGY

under contract DE-AC05-84OR21400

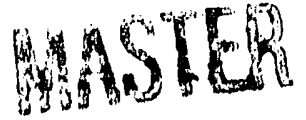

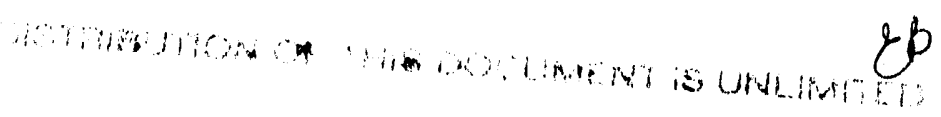




\section{ACTIVE SITES ENVIRONMENTAL MONITORING PROGRAM:}

PROGRAM PLAN

Rev. 1

December 1991

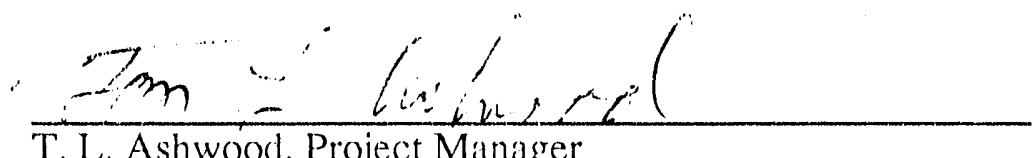

T. L. Ashwood, Project Manager

Environmental Sciences Division

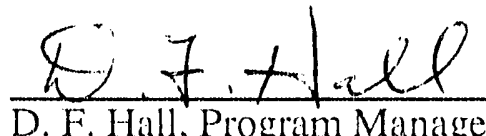

Solid Waste Operations

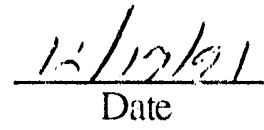

$\frac{12 / 17 / 91}{\text { Ditte }}$ 


\section{CONTENTS}

LIST OF FIGURES

Page

LIST OF TABLES

vii

ABBREVIATIONS AND ACRONYMS

ix

EXECUTIVE SUMMARY

$\mathrm{xi}$

1. INTRODUCTION

xiii

1.1 REGULATORY BACKGROUND AND SCOPE ....................... 1

1.2 ORGANIZATION ..................................................... 2

1.3 QUALITY ASSURANCE .......................................... 3

1.4 HEALTH AND SAFETY ...............................................

2. TECHNICAL BASIS ….................................................. 3

2.1 CONCEPTUAL MODEL ........................................... 3

2.1.1 LLW Disposal Facilities in SWSA 6 .......................... 4

2.1.1.1 Tumulus Facilities and Interim Waste Management Facility ................................................... 4

2.1.1.2 Subsurface LLW Disposal Facilities ...................... 4

2.1.1.3 Hillcut Disposal Test Facility ........................... 5

2.1.2 TRU Waste Storage Facilities in SWSA 5 North ..................... 6

2.2 DATA QUALITY OBJECTIVES .................................... 6

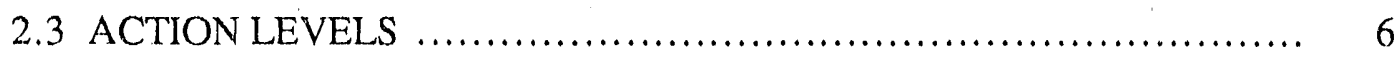

3. METHODOLOGY …................................................ 7

3.1 SWSA 6 FACILITIES …….......................................... 7

3.1.1 Tumulus I and II .................................................. 7

3.1.1.1 Pad Water .......................................... 7

3.1.1.2 Underpad Drain ......................................... 8

3.1.1.3 Groundwater ............................................... 8

3.1.1.4 Meteorological Station ............................... 8

3.1.2 Interim Waste Management Facility ............................ 9

3.1.2.1 Pad Runoff .................................................. 9

3.1.2.2 Underpad Drainage ...................................... 9

3.1.2.3 French Drain ........................................... 9

3.1.2.4 Groundwater .............................................. 9

3.1.3 Silos, Fissile Wells, High-Range Wells, and Asbestos Silos ........ 10

3.1.4 Hillcut Disposal Test Facility .................................... 10

3.2 SWSA 5 NORTH FACILITIES ……..................................... 10

3.2.1 Groundwater Wells ........................................ 11

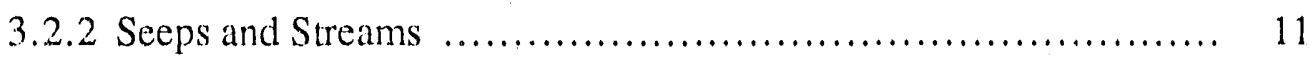




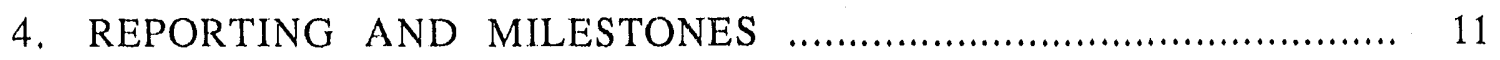

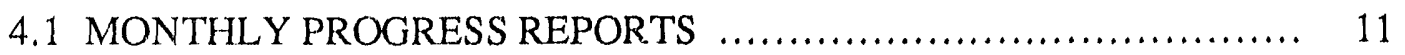

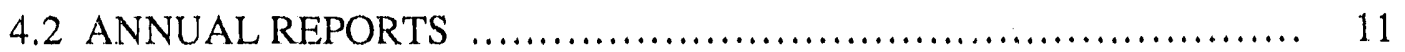

4.3 EXCEPTION REPORTS/ACTION PLANS .......................... 11

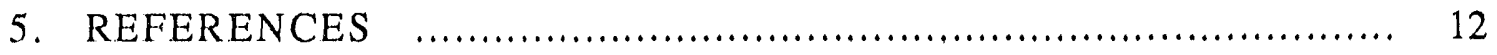

APPENDIX A: FIGURES ......................................... A-1

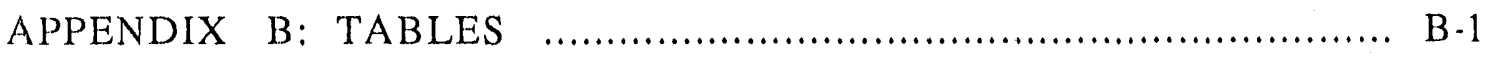

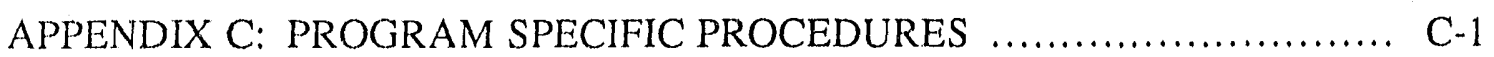




\section{vii \\ LIST OF FIGURES}

Figure

Page

A.1 Active low-level waste disposal sites and other major facilities in SWSA 6

A.2 Transuranic waste storage sites and sampling locations in SWSA 5 North

A.3 Organization of active sites environmental monitoring program ........... A-5

A.4 Typical cross section of LLW disposal trench ........................ A-6

A.5 Schematic of Hillcut Disposal Test Facility ............................ A-7

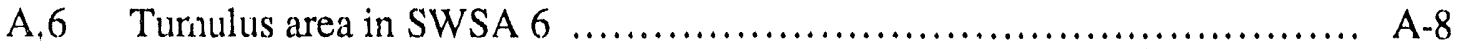

A.7 Locations of intratrench wells in SWSA 6 low-activity silos area north .... A-9

A.8 Locations of intratrench wells in SWSA 6 high-activity silos area ......... A-10

A.9 Locations of intratrench wells in SWSA 6 low-activity silos area south ..... A-11

A.10 Locations of new wells near SWSA 6 high-range wells, fissile wells, and asbestos silos 
ix

\section{LIST OF TABLES}

Figure

Page

B.1 Action levels for active sites environmental monitoring in SWSA 5 North and SWSA 6

B.2 Sample frequency and analytes for tumulus area in SWSA 6

B-4

B.3 Sample frequency and analytes for groundwater wells around tumulus area and interim waste management facility in SWSA 6

B-5

B.4 Sample frequency and analytes for interim waste management facility in SWSA 6

B-6

B.5 Sample frequency and analytes for groundwater and surface water in SWSA 5 North

B-7 
$\mathrm{xi}$

\section{ABBREVIATIONS AND ACRONYMS}

ASEMP Active Sites Environmental Monitoring Program

ESD Environmental Sciences Division

HDTF Hillcut Disposal Test Facility

IWMF Interim Waste Management Facility

LLW Low-level waste

NPDES National Pollutant Discharge Elimination System

ORNL Oak Ridge National Laboratory

OWMRA Office of Waste Management and Remedial Actions

PWTP Process Waste Treatment Plant

QA Quality Assurance

RCRA Resource Conservation and Recovery Act

SWSA Solid Waste Storage Area

TRU Transuranic 


\section{xiii \\ EXECUTIVE SUMMARY}

The Actives Sites Environmental Monitoring Program (ASEMP), initiated in 1989, provides early detection and performance monitoring of transuranic (TRU) waste and active low-level waste (LLW) facilities at Oak Ridge National Laboratory (ORNL) in accordance with U.S. Department of Energy (DOE) Order 5820.2A. The program is implemented by the Environmental Sciences Division for Solid Waste Operations. After 2 years of experience, several revisions in the original program plan are required. This document incorporates those revisions.

Active LLW facilities in Solid Waste Storage Area (SWSA) 6 include Tumulus I and Tumulus II, the Interim Waste Management Facility (IWMF), LLW silos, high-range wells, asbestos silos, and fissile wells. The tumulus pads and IWMF are aboveground, high-strength concrete pads on which concrete vaults containing metal boxes of LLW are placed; the void space between the boxes and vaults is filled with grout. Eventually, these pads and vaults will be covered by an engineered multilayered cap. All other LLW facilities in SWSA 6 are below ground. In addition, this plan includes monitoring of the Hillcut Disposal Test Facility (HDTF) in SWSA 6, even though this facility was completed prior to the date of the DOE order. In SWSA 5 North, the TRU facilities include below-grade engineered caves, high-range wells, and unlined trenches.

Monitoring activities at each facility are based on the most current conceptual model of the hydrology in each area as well as site-specific characteristics. In all areas, water is the primary vector for contaminant transport. In SWSA 6 water can move as shallow stormflow within the upper 1-2 $\mathrm{m}$ of soil or as groundwater in the shallow aquifer. As stormflow intercepts the unlined burial trenches, water enters the trenches faster than it can flow out, and a perched water table is formed. This perched water table subsequently acts to recharge the shallow aquifer. Hence, it is important to monitor the perched water table in the trenches and in the small quantity of backfill around high-range wells, asbestos silos, and fissile wells.

The tumulus pads and IWMF are aboveground facilities that require a different monitoring approach from that for buried wastes. The pads provide the first line of containment for any waste material that might escape from the concrete vaults. Water accumulating on, or running off, the pads is monitored. Should the pads also leak, the gravel base below the pads would accumulate the contamination, and that water is also drained away from the pads and monitored. Groundwater around the pads is also monitored to determine if any contamination has escaped from the pads and gravel base and to provide the hydrogeochemical data to predict the rate of transport should any contamination be detected.

The perched water table in the LLW silo trenches is sampled through the use of wells that are installed in the trench backfill. Similar wells are also installed in the backfill adjacent to the high-range wells, asbestos silos, and fissile wells.

The HDTF, which is very similar to a tumulus-type facility that is already buried, is monitored through collection and sampling of water that accumulates on the concrete pad and in the gravel base. Monitoring wells have also been installed on the pad and into the gravel base, and these wells are checked regularly.

In SWSA 5 North, there is evidence that transport through the shallow aquifer, especially along preferred pathways, may be more important than shallow stormflow. 
xiv

Thus, in this area, monitoring activities focus on groundwater monitoring wells, seeps, and samples from small tributaries.

All samples from SWSA 6 are screened for alpha and beta activity, counted for gamma-emitting isotopes, and analyzed for tritium. In addition to these analytes, samples from SWSA 5 North are analyzed for specific transuranic elements.

This program plan provides the organization and procedures for accomplishing the active sites monitoring. The program plan also provides action levels to guide the evaluation of monitoring results. 


\section{INTRODUCTION}

The Active Sites Environmental Monitoring Program (ASEMP) was initiated in 1989. The program is funded through the Solid Waste Operations (SWO) Department of the Office of Waste Management and Remedial Action (OWMRA) at Oak Ridge National Laboratory (ORNL) and is implemented by the Environmental Sciences Division (ESD). Results of the first two years of monitoring activities are documented in four semiannual reports (Wickliff et al. 1991a,b; Ashwood et al. $1991 \mathrm{a}, \mathrm{b}$ ).

This document presents changes to the original program plan (Ashwood et al. 1990i) that have been identified in the first 2 years of monitoring. In addition, this revision incorporates monitoring activities at the Interim Waste Management Facility (IWMF), which began cperation in December 1991. Finally, the detailed procedures used to accomplish the monitoring are now documented in Appendix $\mathrm{C}$ of this report.

The introduction to this report provides information on the background and scope (Sect 1.1), project organization (Sect 1.2), and quality assurance (QA) and health and safety concerns (Sects. $1.3 \& 1.4$ ). Section 2 describes the technical basis for the program. Section 3 includes specific monitoring activities for each facility. Reporting and milestones are addressed in Sect. 4. Detailed monitoring procedures are included in an appendix.

\subsection{REGULATORY BACKGROUND AND SCOPE}

Chapter III of DOE Order 5820.2A (U.S. DOE 1988) sets forth requirements for environmental monitoring of operational low-level waste (LLW) disposal facilities. Two statements from this order are included here because they set the framework for the ASEMP activities in Solid Waste Storage Area (SWSA) 6.

"The environmental monitoring program shall be designed to measure: (a) operational effluent releases; (b) migration of radionuclides; (c) disposal unit subsidence; and (d) changes in disposal facility and disposal site parameters which may affect long-term site performance." [Sect. 3.k.2]

"The monitoring program shall be capable of detecting changing trends in performance sufficiently in advance to allow application of any necessary corrective action prior to exceeding performance objectives. The monitoring program shall be able to ascertain whether or not effluents from each... disposal facility or disposal site meet the requirements of applicable EH Orders." [Sect. 3.k.4]

Performance monitoring associated with Tumulus I, Tumulus II, and IWMF (Fig. A.1) is required under Chap. III, Sect. 3.b(3) of the order.

"Where practical, monitoring measurements to evaluate actual and
prospective performance should be made at locations as required, within
and outside each facility and disposal site. Monitoring should also be used
to validate or modify the models used in performance assessments."

The transuranic (TRU) waste storage areas in SWSA 5 North (Fig. A.2) are covered in Chap. II of the order. Environmental monitoring is required as follows for temporary and interim storage. 
"Transuranic wastes in storage areas shall be monitored periodically to ensure that the wastes are not releasing their radioactive and/or hazardous constituents." [Sect. 3.e(4)]

"An environmental monitoring system shall be provided to detect any release and migration of major radioactive and hazardous components. Background levels of primary radioactive and hazardous waste components shall be determined." [Sect. 3.g(2)(c)]

The scope of this program includes all ORNL waste disposal sites that were active on or after the date of the order (September 1988). In SWSA 6, the monitored active sites include the high-activity and low-activity silos, the high-range wells, ${ }^{1}$ the fissile wells, the asbestos silos, Tumulus I, Tumulus II, and the IWMF (Fig. A.1).

The biological trenches in SWSA 6 are not included because those trenches active since September 1988 have received only trivial amounts of radioactive materials (John Van Cleve, ORNL, personal communication, 1989). The suspect waste landfill contains waste ihat has been surveyed by radiation protection personnel and found to be clean. The waste is suspected to be clean throughout, but cannot be so certified because not all portions of the waste could be certified. It is assumed, therefore, that the suspect waste landfill contains only trivial quantities of LLW. Furthermore, groundwater and surface runoff in the vicinity of the suspect waste landfill is potentially contaminated by other sources, thereby making monitoring of leaks from the landfill impractical.

This plan also addresses monitoring activities associated with the Hillcut Disposal Test Facility (HDTF) in SWSA 6 (Fig. A.2), although that facility was not active on or after the date of the DOE order.

Compliance monitoring required under the Resource Conservation and Recovery Act (RCRA) or for National Pollutant Discharge Elimination System (NPDIES) permits is not included in this program. Although information can be shared among these various monitoring programs, the quality assurance requirements and monitoring approaches are so different that data from ASEMP cannot be used for environmental compliance monitoring.

\subsection{ORGANIZATION}

The ASEMP is implemented by a staff of five individuals from ESD (Fig. A.3). Overall project direction is provided by the project manager, while individual monitoring tasks are performed under the direction of principal investigators for each major program area (i.e., tumulus-type facilities, subsurface LLW facilities, TRU facilities).

Close coordination is maintained with SWO personnel in each SWSA, and information is shared as needed with environmental restoration activities. Monthly and annual reports (Sect. 5) are issued to all individuals within ORNL who have an interest in the program, including representatives of waste management operations, environmental monitoring, and environmental restoration organizations.

${ }^{1}$ Preceding ASt MP reports refer to these wells as high-activity auger holes. The change is being made here to more arcurately reflect the nature of the wells. 


\subsection{QUALITY ASSURANCE}

This program is conducted in accordance with the QA program of ESD (Roberson and Logsdon 1989), which is consistent with DOE order 5700.6 and ANSI/ASME NQA-1.2 A separate QA plan (Ashwood 1991) has been prepared and will be updated as necessary.

Specific procedures have been prepared for each monitoring activity (Appendix C). All project personnel have received appropriate training in these procedures as well as training required to enter the SWSAs.

\subsection{HEALTH AND SAFETY}

Each monitoring activity is covered by a Project Safety Summary approved by the Division Safety Officer. All project personnel have received at least $24 \mathrm{~h}$ of training required for entry into the SWSAs as well as annual updates. All project personnel are on the ORNL bioassay program. Monitoring activities with a high potential for exposure to ionizing radiation (e.g., sampling of wells adjacent to high-range wells) are accomplished under the guidance of a health physics technician.

\section{TECHNICAL BASIS}

This section describes the basic hydrologic concepts that guide the monitoring activities and the manner in which these concepts are applied at each facility. Data quality objectives and action levels are also discussed.

\subsection{CONCEPTUAL MODEL}

The primary vehicle of contaminant transport in SWSA 5 North and SWSA 6 is water. Both areas receive $\sim 130 \mathrm{~cm}$ of rainfall per year (Moore 1989). Rainfall occurs throughout the year and occurs both as brief showers and as large storms. Slightly more than half of this rainfall is returned to the atmosphere through evapotranspiration (Moore 1989 ). Thus, $\sim 60 \mathrm{~cm}$ of rainfall per year is available to transport contaminants.

Because water is the primary transport vehicle, the conceptual model of contaminant transport for each facility relies on fundamental hydrologic concepts and the specific characteristics of the facility. Monitoring activities are designed on a facility-specific basis that reflects the conceptual model.

${ }^{2}$ Quality Assurance Standard Requirements for Nuclear Facilities. American National Standards Institute/American Society of Mechanical Engineers Nuclear Quality Assurance, Revision 1. 


\subsubsection{LLW Disposal Facilities in SWSA 6}

\subsubsection{Tumulus Facilities and Interim Waste Management Facility}

Tumulus facilities are concrete pads on which are placed concrete vaults containing LLW in a grout mixture. During loading operations the pads are uncovered and open to direct precipitation. Following loading, the pads are covered with a temporary cover that eliminates most, but not all, of the precipitation on the pads and vaults. At some time in the future, the pads will be covered with an engineered cap that will more completely eliminate infiltration of rain water. The IWMF is a tumulus-type facility that will eventually contain at least six pads with concrete vaults.

Because the tumulus facilities are above ground, the primary vector for contaminant transport is rain water falling on the vaults and pads. Water accumulating on the pads is either drained away and discharged to a surface stream (under an NPDES permit) or pumped to a tank truck and transported to the ORNL Process Waste Treatment Plant. The pad is the first line of containment in the event of a release of contaminants from the vaults. Under the pad is a gravel base that would receive any water leaking through the pad. This gravel base may also receive water from shallow stormflow. The gravel base is drained to a surface stream. Finally, water that passes through the pad and is not drained away by the gravel base drain infiltrates to the shallow aquifer.

The conceptual model for the IWMF differs from that for the Tumulus I and Tumulus II only in that there is a French drain between the IWMF and the hill to the north. This drain is designed to prevent groundwater from entering the gravel base under the pads. The IWMF gravel base will also drain to the surface stream. Some portion of water that infiltrates the ground beneath the gravel base would also be intercepted by the French drain. The remainder of any water passing through the gravel base would infiltrate to the shallow aquifer.

\subsubsection{Subsurface LLW Disposal Facilities}

In June 1986 ORNL decided to abandon the use of unlined trenches and auger holes in favor of a greater confinement silo disposal concept for LLW (Davis et al. 1989). This concept involves cylindrical concrete silos placed below grade in an upright fashion (Fig. A.4). The silos are installed in groups of two to four within a single trench. The trench is backfilled with soil around the silos. After it was discovered that water leaked into the silos, three corrective actions were implemented: (1) changes in construction of the silos to form a concrete-to-concrete joint between the sidewalls and bottom, (2) recapping of the silos with a concrete cover, and (3) grouting of the waste within the silos, beginning with silo 567 (Davis et al. 1989).

Moore $(1988,1989)$ suggests that most of the subsurface flow in the ORNL area occurs laterally in a shallow stormflow zone ( $\leq 2 \mathrm{~m}$ deep). This zone typically has a hydraulic conductivity much greater than deeper zones and is active when infiltrating precipitation exceeds the soil moisture deficit (Moore 1988, 1989). Water in the stormflow zone moves rapidly to surface water drainages. As a result of this rapid lateral movement to the surface drainages, only a small fraction of the precipitation is available to recharge the shallow aquifer.

In SWSA 6, waste trenches are typically installed at least $0.6 \mathrm{~m}(2 \mathrm{ft})$ above the highest recorded water table (Boegly 1984). While these trenches are not in contact with 
the shallow aquifer, they may intercept shallow stormflow (Fig. A.4). Because the permeability of the trenches is substantially higher than that of the surrounding soil, water flows into the trenches faster than it can flow out, thereby creating a perched water table. This bathtubbing effect accounts for saturated conditions in trenches that are above the local water table.

Solomon et al. (1988) summarized water level data collected from 1975 to 1988 from unlined waste trenches in SWSA 6 . They estimated that $85 \%$ of the trenches had standing water during some part of that period. Ashwood and Spalding (1991) measured water levels in unlined SWSA 6 trenches covered by plastic caps. They demonstrated that some trenches that were above the water table continued to receive water (probably via shallow subsurface stormflow) even after direct infiltration had been eliminated by the caps.

Understanding the movement of water through the disposal and storage areas is important because water is the primary vector for transport of contamination. Within a trench, contamination may be present in the perched water from one of three sources: (1) leaching of material from the silos if there has been a containment failure in the silo, (2) leaching of contaminants from the backfill in the trench if that backfill was contaminated, or (3) transport of contaminants from upgradient sources in the stormflow zone or in upgradient trenches.

Asbestos waste suspected of containing LLW contamination is placed in single silos similar to the LLW silos. It is hypothesized that the small quantity of backfill surrounding the individual silos is subject to the same bathtubbing effect as the trenches.

High-range wells and fissile wells are used for the disposal of high-activity LLW and fissile material, respectively. High-range wells and fissile wells are lined with a steel pipe having a concrete bottom and a concrete plug cap. In some cases, several high-range wells are grouped within a small area having a single concrete cap. Wastes are not grouted in the high-range wells. The small amount of backfill surrounding the steel pipe in the high-range wells is expected to be subject to the same bathtubbing effect as the trenches.

\subsubsection{Hillcut Disposal Test Facility}

The Hillcut Disposal Test Facility (HDTF) is a demonstration project that was started in 1981 but discontinued the following year before any wastes were emplaced (see Fig. A.2 for location). In 1985, the project was reactivated as part of the Low-Level Waste Disposal Development and Demonstration project. The HDTF provided a method for disposing of high-activity LLW because no suitable greater-confinement burial method was available at the time. The HDTF demonstration also provided a means to evaluate the use of hillslope cuts as possible sites for future engineered disposal facilities. The objective of the demonstration was to assess the degree of hydrologic isolation afforded by this type of design.

The HDTF is similar to the tumulus facilities and consists of a concrete pad $(4.6 \mathrm{mx}$ $4.6 \mathrm{~m}$ ) constructed in a cut from the side slope of a hill (Fig. A.5). The pad was installed above the expected high water table in the area. Twenty-seven concrete boxes $(1.1 \mathrm{~m} \times 1.1$ $\mathrm{m} \times 1.4 \mathrm{~m}$ ) of high-activity LLW were placed on the pad and covered with soil. The lids of the boxes were sealed with a bitumen mastic, and the boxes were banded. A runoff collection system was installed to drain both the pad and the gravel area surrounding the pad. Runoff from the pad and the gravel drain are collected separately in two above-grade 500-gal tanks. Two monitoring wells were installed, one on the pad and one in the gravel drain (Fig. A.5). 
Water can reach the buried waste vaults through infiltrating precipitation or shallow stormflow. If the water table were to rise following heavy rains, the gravel base below the pad should intercept water from the shallow aquifer, serving as a wick to drain the water away from the pad.

\subsubsection{TRU Waste Storage Facilities in SWSA 5 North}

Active TRU waste management facilities in SWSA 5 North include aboveground buildings, buildings that are below ground on three sides, and auger holes similar to the high-range wells in SWSA 6 . The buildings all have sumps that collect any water that enters the waste storage areas.

Prior to the date of the DOE order, TRU wastes were also emplaced in unlined trenches in SWSA 5 North. Within the trenches, TRU wastes are contained in concrete casks and wooden and metal boxes (Stewart et al. 1989). These trenches are probably subject to the bathtubbing effect, and there is evidence that the shallow aquifer extends above the bottom of at least some of the trenches during high water table conditions (Wickliff et al. 1991b). Furthermore, TRU contamination leached from wastes in the trenches has been measured in a downgradient well (Ashwood et al. 1990b; Wickliff et al. $1991 \mathrm{a}, \mathrm{b}$; Ashwood et al. 1991a,b) and in seeps along the bank of White Oak Creek (Ashwood et al. 1991a,b). Thus, transport from the trenches is known to occur through the shallow aquifer and along discrete pathways.

\subsection{DATA QUALITY OBJECTIVES}

Data from this program are not used in compliance with any federal environmental regulations. Therefore, U.S. Environmental Protection Agency guidelines for data quality objectives are not applicable to this program. Data from this program are used by SWO personnel to manage their operations in accordance with DOE Order $5820.2 \mathrm{~A}$ and to assess the performance of LLW disposal facilities.

Monitoring activities must ensure that any contaminant transport from the active LLW and TRU facilities is detected in sufficient time to allow SWO personnel to take appropriate corrective action. Sample collection must be sufficiently representative of affected media to ensure that contaminant pathways are not missed, and analytical techniques must be sufficiently sensitive to detect contamination at levels above background. Furthermore, there must be sufficient geochemical and hydrologic data available to evaluate the potential risks from any detected leaks.

\subsection{ACTION LEVELS}

Many of the radioisotopes that are contained in LLW (e.g., ${ }^{3} \mathrm{H},{ }^{90} \mathrm{Sr}$, and ${ }^{137} \mathrm{Cs}$ ) are also present in the environment due to radioactive fallout. These isotopes (except ${ }^{3} \mathrm{H}$ ) and naturally occurring isotopes (e.g., ${ }^{40} \mathrm{~K}, \mathrm{Ra}, \mathrm{Rn}, \mathrm{Th}$, and $\mathrm{U}$ ) also contribute to the activity measured in gross alpha and gross beta analyses. Leak detection at LLW and TRU facilities depends upon the capability to identify contamination above the background concentrations of naturally occurring and fallout-derived radioisotopes. Thus, a determination of the range of background concentrations was conducted (Ashwood and Ashwood 1991). Based on this study, action levels (Table B.1) have been established that typically provide $90 \%$ confidence that $90-95 \%$ of the measured background concentrations 
will fall below the action level. Thus, any samples where the measured concentration exceeds an action level are highily likely to indicate contamination from the monitored facility.

Any samples that exceed an action level are reported to SWO immediately upon receipt of the results by the ESD project manager. Depending upon the location of the sample, the analyte involved, and the magnitude of the exceedance, a decision is then made as to appropriate followup action.

\section{METHODOLOGY}

This section describes the monitoring activities associated with each active LLW and TRU facility. These activities are based on the conceptual model for the facility as described in Sect. 2.1 and the data quality objectives in Sect. 2.2. Each subsection includes a summary of the salient results from the first 2 years of monitoring. Unless otherwise noted, the results are based on the semi-annual reports (Wickliff et al. 1991a,b; Ashwood et al. 1991a,b). Procedures for each of the monitoring activities described herein are included in Appendix $\mathrm{C}$.

\subsection{SWSA 6 FACILITIES}

\subsubsection{Tumulus I and II}

The $\mathrm{pH}$ of water that accumulates on both pads (from rainfall) has increased with increasing numbers of vaults on the pads. Once most of the vaults were on the pad, the $\mathrm{pH}$ frequently exceeded the 9.0 level in the NPDES permit.

Water accumulating on the Tumulus I pad has exceeded the gross beta action level (5.0 Bq/L) in every sample since completion of pad loading and installation of a temporary cover. The cause of this beta activity is ${ }^{40} \mathrm{~K}$, which is suspected to be leached from the concrete of the vaults and pad. Specific conductance of the water from Tumulus I is also quite high $(>1500 \mu \mathrm{S} / \mathrm{cm})$, further suggesting leaching of ions from the concrete.

Tritium activity in water accumulating on Tumulus II and in the underpad drain beneath Tumulus II has been measured at levels well in excess of background. This ${ }^{3} \mathrm{H}$ is believed to have come from a vault on the pad, and relocation of that vault resulted in substantial reduction of the ${ }^{3} \mathrm{H}$ concentrations in the pad and underpad areas. Tritium was also detected in two wells by Tumulus I that are along geologic strike with the discharge of the French drain (Davis et al. 1985). SWO personnel have moved the discharge point of this French drain in an attempt to eliminate the suspected source of the ${ }^{3} \mathrm{H}$ plume.

\subsubsection{Pad Water}

Monitoring of water accumulating on the tumulus pads has changed completely from the original ASEMP plan (Ashwood et al. 1990a). The presence of high pH and high gross beta activity led SWO personnel to cease discharges of runoff from the pads through the monitoring shed (Fig. A.6). Water that accumulates on the pads is now pumped into a tank truck and transported to the Process Waste Treatment Plant (PWTP). Prior to 
pumping, a sample is collected and analyzed as indicated in Table B.2. No measurement of water volume is made, and no flow-proportional sample is collected.

Both tumulus pads are scheduled to be covered with an improved temporary cover in early FY 1992. If successful, this new cover should substantially reduce the volume of water accumulating on the pads. At that time, monitoring of pad water will be modified to inspection of the pads following each major rain event and grab sampling of any water found during the inspection. SWO personnel will decide when sufficient water has accumulated to justify transfer to the PWTP.

\subsubsection{Underpad Drain}

The underpad area beneath Tumulus I is divided into two zones. The gravel layer immediately beneath the pad is sealed from the surrounding soil by a plastic membrane. This underpad area is drained to a sump in the monitoring shed (Fig. A.6). Beneath the plastic seal is a gravel layer called the construction base drain that is drained directly to the surface stream.

Any water that accumulates in the Tumulus I underpad drain sump is sampled and then pumped to the discharge line from the monitoring shed. The sample is analyzed as indicated in Table B.2. Once a quarter, a sample is collected from the construction base drain and analyzed as indicated in Table B.2.

The underpad area beneath Tumulus II is unsealed and drains directly to the surface stream (Fig. A.6). Once a quarter, this discharge is sampled and analyzed as indicated in Table B.2.

These monitoring activities will continue after installation of the new temporary cover.

\subsubsection{Groundwater}

Twelve monitoring wells surround the tumulus pads (Fig. A.6). Construction data on these wells (except well 381) are included in Wickliff et al. (1991b). The original ASEMP plan required continuous monitoring of water levels in these wells. However, the utility of the volume of data generated by such continuous monitoring was not sufficient to justify the cost of maintaining the pressure transducers and data loggers. At present, water levels are measured manually once every 2 weeks.

The wells (except well 381) are sampled quarterly and analyzed as indicated in Table B.3. Once a year, six randomly chosen wells are sampled and analyzed for the water quality parameters indicated in Table B.3.

\subsubsection{Meteorological Station}

The meteorological station (Fig. A.6) provides continuous measurements of rainfall, solar irradiance, wind speed and direction, relative humidity, and temperature. Data from the instrumentation are stored in a data logger that is downloaded monthly or as needed. 


\subsubsection{Interim Waste Management Facility}

The IWMF will become operational in early FY 1992. Initially, only one pair of pads will be available, but eventually at least six pads will be constructed. Preconstruction monitoring has been limited to sampling and hydrologic testing of ten wells that existed in the area prior to construction. Results from these limited tests revealed that the groundwater flow in the area is probably to the southeast toward the surface stream, hydraulic conductivity is relatively low $\left(\sim 10^{-6} \mathrm{~cm} / \mathrm{sec}\right)$, and no radioactive or trace metal contamination occurrs in the shallow aquifer (Wickliff et al, 1991a).

\subsubsection{Pad Runoff}

Runoff from the active pad will be collected in a sump in the monitoring shed. Runoff from covered inactive pads will also drain to a separate sump in the monitoring shed. The volume of each sump is $~ 7500 \mathrm{~L}$ ( $2000 \mathrm{gal})$. From the sumps, the water can either be pumped to a tank truck for disposal at the PWTP or allowed to flow through a flume and discharge to the surface stream.

Discharge through the flume will be measured, and a flow-proportional sample wiil be collected. A grab sample will be collected from water that is pumped to a tank truck. Samples will be analyzed for the constituents indicated in Table B.4. Initially, all water will be pumped to the tank truck until the NPDES permit for the facility is received.

\subsubsection{Underpad Drainage}

The underpad gravel base drain is collected in an $~ 3800$-L (1000)-gal) sump in the monitoring shed. From the sump, underpad drainage can be discharged via the flume or pumped to a tank truck for disposal at the PWTP.

Discharge through the flume will be measured, and a flow-proportional sample will be collected of water discharged to the surface stream. A grab sample will be collected from water that is pumped to a tank truck. Samples will be analyzed as indicated in Table B.4.

\subsubsection{French Drain}

The IWMF French drain discharges directly to the surface stream. Water from this drain is not expected to be contaminated. A sample will be collected quarterly from the French drain and analyzed as indicated in Table B.4.

\subsubsection{Ground water}

The following existing wells that surround the IWMF will be sampled quarterly and analyzed as indicated in Table B.3: well 380 west of the IWMF area, well 1236 northwest of the IWMF area, and well 377 north of the IWMF area. In addition, three monitoring wells will be installed downgradient of the IWMF area to evaluate the performance of the French drain and to monitor groundwater passing under the facility. The new wells will also be sampled quarterly and analyzed as indicated in Table B.3. 
Water levels in the existing wells will be measured every 2 weeks. Pressure transducers will be installed in the new wells, and water level measurements will be taken every $15 \mathrm{~min}$ for a period of 2 years. After that time, the need for continuous water-level monitoring will be reevaluated.

\subsubsection{Silos, Fissile Wells, High-Range Wells, and Asbestos Silos}

Wells have been installed in the backfill of LLW silo trenches and in the backfill around active high-range wells, asbestos silos, and fissile wells (Figs. A.7-A.10). These wells are equipped with weighted sample bottles that collect a sample of bathtubbing water in the backfill. The bottles are inspected once a quarter, and water (if $\geq 50 \mathrm{~mL}$ ) is collected and analyzed for gross alpha activity, gross beta activity, and gamma-emitting radionuclides. If results of a quarterly sample indicate the presence of contamination above action levels, a second sample is collected as soon as possible to confirm the presence of the contaminant.

Strontium-90 has consistently been measured in intratrench well 19 (Fig. A.7) at levels exceeding the gross beta action level. This well is in a trench where the silos were installed without grouting the waste. Other intratrench wells and wells adjacent to high-range wells have shown temporally sporadic patterns of contamination above action levels.

As new high-range wells and silos are installed, wells will be installed and equipped with sample bottles.

\subsubsection{Hillcut Disposal Test Facility}

Measurements of the volume in each tank are made and recorded weekly. When water in either tank reaches $\sim 70 \%$ of tank volume, a sample is collected and the contents of the tank are transferred to a holding tank. The sample is analyzed for gross alpha, gross beta, and gamma activity. If radioactivity concentrations are below the action levels, holding tank contents are drained locally, after the Environmental Compliance Monitoring personnel have been notified and have given their concurrence. If radioactivity levels are above the action levels, SWO personnel will be notified, and an action plan will be developed to identify the source of the contamination and dispose of the water.

Wells on the pad and in the gravel base will be monitored weekly for water levels. Samples will be obtained whenever the water levels indicate that water in the drain is over the top of the curb around the pad. Samples will be analyzed for gross alpha, gross beta, and gamma activity.

To date, no contamination has been found in water draining from either the pad or the gravel base. The well in the gravel base is almost always dry, and the well on the pad consistently shows $\sim 1 \mathrm{~cm}$ of water standing on the pad.

\subsection{SWSA 5 NORTH FACILITIES}

The sumps in each building are sampled by SWO personnel and are not included in this program. However, should contaminants be found in any of the sumps, the ASEMP team should be notified by SWO personnel so that an action plan for further investigation of the leaks can be developed. 
The burial trenches in SWSA 5 North are being included in the remedial investigation of Waste Area Grouping 5, which also includes the rest of SWSA 5. At some point in the future these trenches may no longer be considered to be part of the active sites monitoring program, and at that time a decision will be made as to what, if any, changes are required in this monitoring plan.

\subsubsection{Groundwater Wells}

Wells indicated in Fig. A.1 are sampled quarterly and analyzed as shown in Table B.5. Water levels are recorded in each well at the time of sampling.

To date, only well 516 has contained TRU contamination. This well is hydrologically downgradient from the burial trenches (Fig. A.1) and has contained gross alpha activity (primarily from ${ }^{244} \mathrm{Cm}$ and ${ }^{241} \mathrm{Am}$ ) since monitoring activities began. No trace metal or organic contamination has been detected in well 516.

\subsubsection{Seeps and Streams}

Streams and seeps (Fig. A.1) are sampled quarterly and analyzed as indicated in Table B.5.

Monitoring data indicate that two seeps in the bank of White Oak Creek (WOC 213 and WOC 255) contain measurable concentrations of ${ }^{244} \mathrm{Cm}$ and $241 \mathrm{Am}$. No other seeps or stream samples have contained TRU isotopes.

\section{REPORTING AND MILESTONES}

\subsection{MONTHLY PROGRESS REPORTS}

Activities conducted each month, together with any analyses received, will be summarized in a letter report, which will be issued by the fifth day of the following month. This letter report will also include a schedule of the next month's activities.

\subsection{ANNUAL REPORTS}

A detailed report with the results of all ASEMP activities will be issued annually. A draft copy of the report will be issued by the 15 th working day of October following the close of the reporting period (e.g., the draft FY 1991 report was issued on 21 October 1991). After review by SWO and ESD staff, the report will be issued as an ORNL/M report.

\subsection{EXCEPTION REPORTS/ACTION PLANS}

Samples that exceed an established action level or that otherwise indicate a problem will be reported to SWO personnel by the most immediate method (usually electronic mail or a telephone call). Depending upon the nature of the problem, an action plan may be 
prepared describing those actions to further investigate and/or remedy the problem, including any follow-up documentation.

\section{REFERENCES}

Ashwood, J. S., and T. L. Ashwood. 1991. Active sites environmental monitoring program: Action levels. ORNL/M-1569. Oak Ridge National Laboratory.

Ashwood, T. L. 1991. Active sites environmental monitoring program: Quality assurance plan. In review.

Ashwood, T. L., and B. P. Spalding. 1991. SWSA 6 interim corrective measures environmental monitoring: FY 1990 results. ORNL/ER-36. Oak Ridge National Laboratory.

Ashwood, T. L., D. S. Wickliff, and C. M. Morrissey. 1990a. Active sites environmental monitoring program: Program plan. ORNL/M-1197. Oak Ridge National Laboratory.

Ashwood, T. L., D. S. Wickliff, C. M. Morrissey, and H. L. Adair. 1990b. Active sites monitoring at Oak Ridge National Laboratory. pp. 397-399. In Proceedings of SPECTRUM 90 Nuclear and Hazardous Waste Management International Topical Meeting, September 30-October 4, 1990, Knoxville, Tennessee. American Nuclear Society, La Grange Park, Ill.

Ashwood, T. L., D. S. Wickliff, and C. M. Morrissey, 1991a. Active sites environmental monitoring program: Mid-FY 1991 report. ORNL/M-1442. Oak Ridge National Laboratory.

Ashwood, T. L., D. S. Wickliff, and C. M. Morrissey. 1991b. Active sites environmental monitoring program: FY 1991 report. ORNL/M-1792. Oak Ridge National Laboratory.

Boegly, W. J. Jr. 1984. Site characterization data for solid waste storage area 6. ORNL/TM-9442. Oak Ridge National Laboratory.

Davis, E. C., R. G. Stansfield, L. A. Melroy, and D. D. Huff. 1985. Water diversion at low-level waste disposal sites. J. Environ. Eng. 111(5):714-29.

Davis, E. C., C. W. Francis, and R. J. Luxmoore. 1989. An evaluation of water leakage into concrete low-level radioactive waste disposal silos at ORNL's solid waste storage area six. ORNL/TM-11164. Oak Ridge National Laboratory, Oak Ridge, Tennessee.

Moore, G. K. 1988. Concepts of groundwater occurrence and flow near Oak Ridge National Laboratory, Tennessee. ORNL/TM-10969. Oak Ridge National Laboratory.

Moore, G. K. 1989. Groundwater parameters and flow systems near Oak Ridge National Laboratory, ORNL/TM-1 1368. Oak Ridge National Laboratory.

Roberson, L. E., and Logsdon, G. M. 1989. Environmental sciences division quality assurance manual. Oak Ridge National Laboratory.

Solomon, D. K., J. D. Marsh, I. L. Larsen, D. S. Wickliff, R. B. Clapp. 1991. Transport of contaminants in the White Oak Creek and Melton Branch watersheds. ORNL/TM-11360. Oak Ridge National Laboratory.

Solomon, D. K., R. C. Haese, T. V. Dinsmore, and A. D. Kelmers. 1988. Sampling and analysis of SWSA 6 trench leachates and groundwaters. ORNL/TM-10813, Oak Ridge National Laboratory.

Stewart, R. C., L. S. Dickerson, S. F. Joost, and D. C. Osucha. 1989. Remote-handled transuranic solid waste characterization study: Oak Ridge National Laboratory. ORNL/TM-11050. Oak Ridge National Laboratory.

U.S. DOE (U. S. Department of Energy). 1988. Radioactive Waste Management. DOE Order 5820.2A, 9/26/88. Washington, D.C. 
13

Wickliff, D. S., C. M. Morrissey, and T. L. Ashwood. 1991a. Active sites environmental monitoring program: Mid-FY 1990 summary report. ORNL/M-1179. Oak Ridge National Laboratory.

Wickliff, D. S., C. M. Morrissey, and T. L. Ashwood. 1991b. Active sites environmental monitoring program: FY 1990 annulal report. ORNL/M-1327. Oak Ridge National Laboratory. 
APPENDIX A

FIGURES 


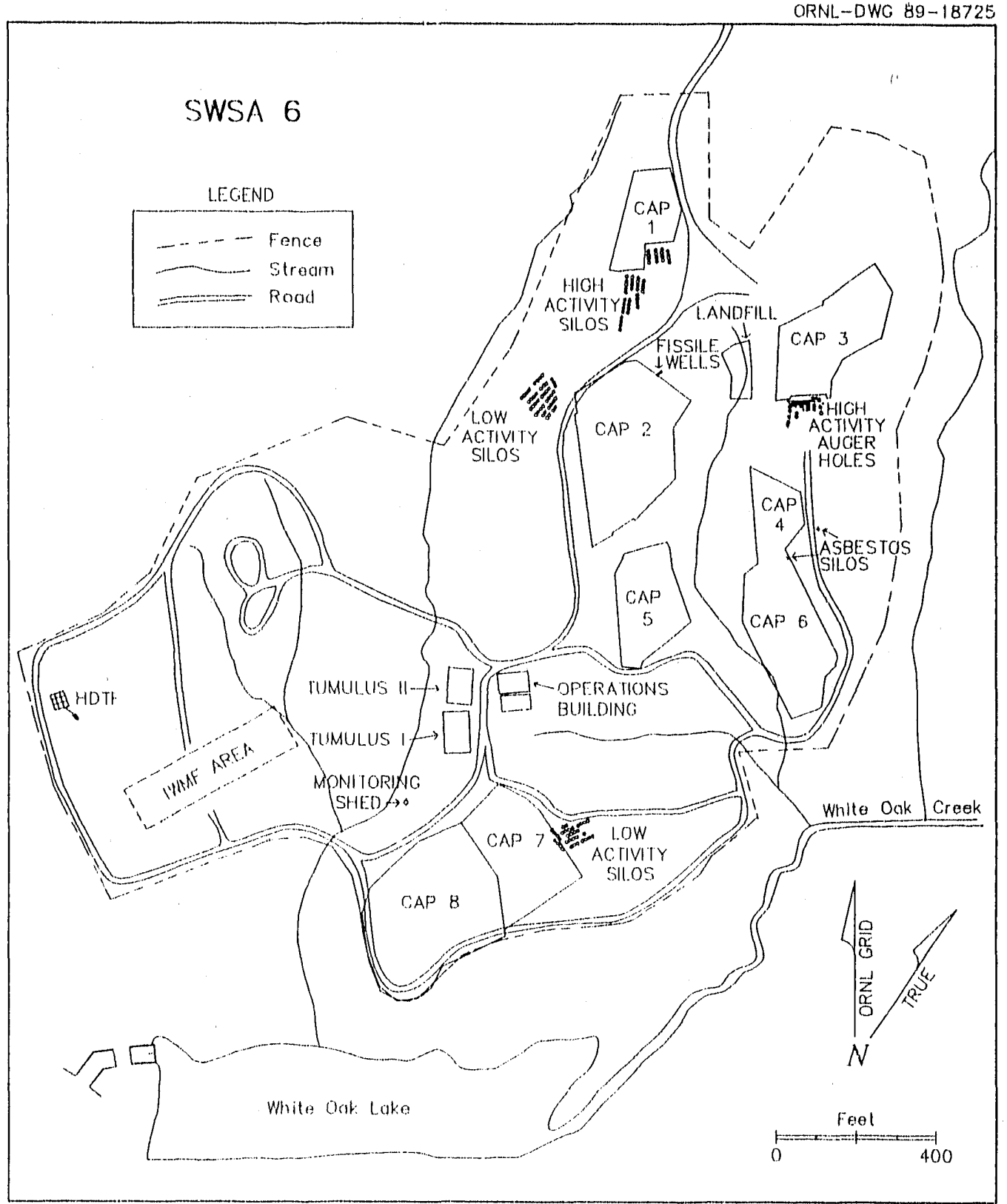

Fig. A.1. Active low-level waste disposal sites and other major facilities in SWSA 6. 


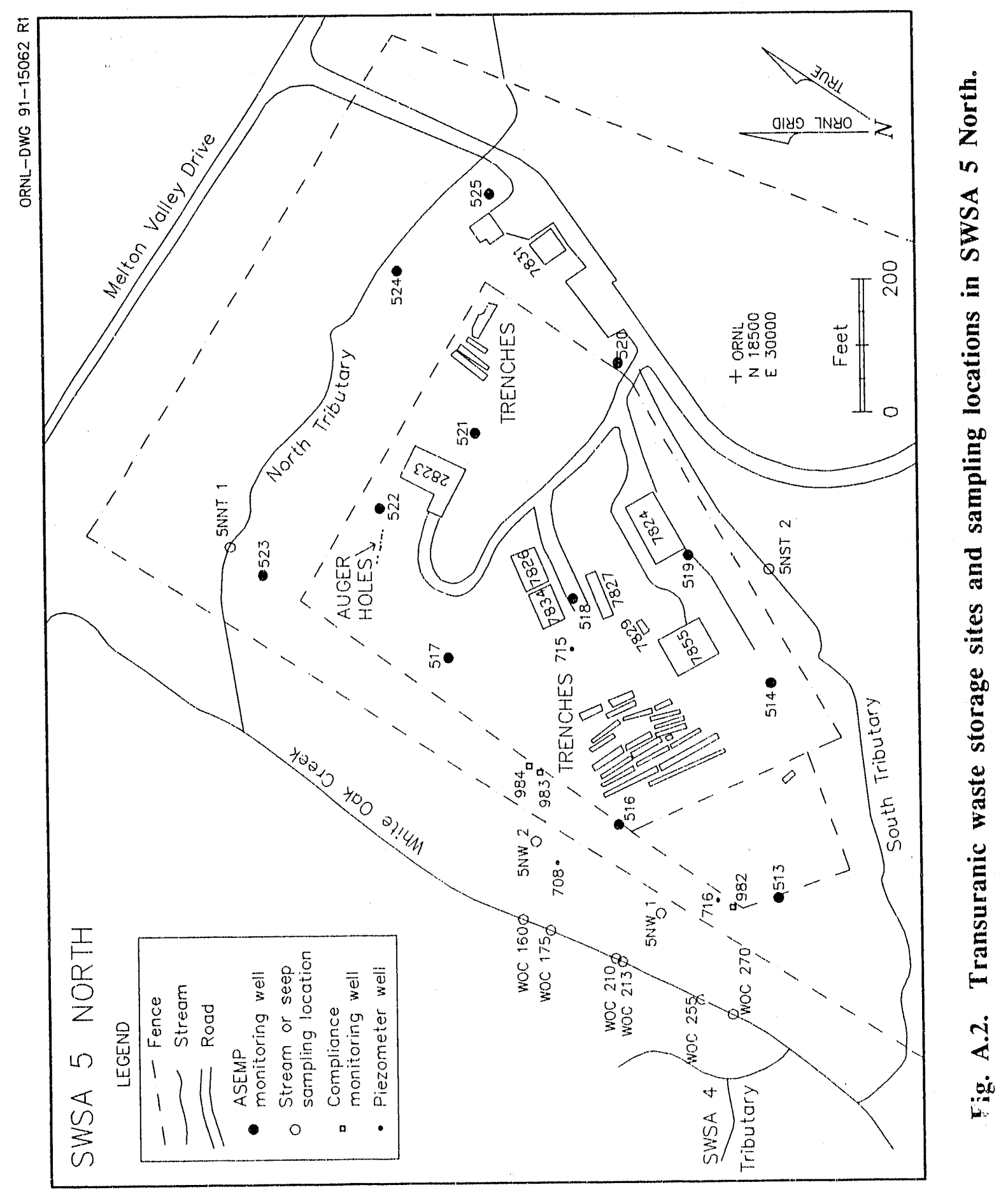




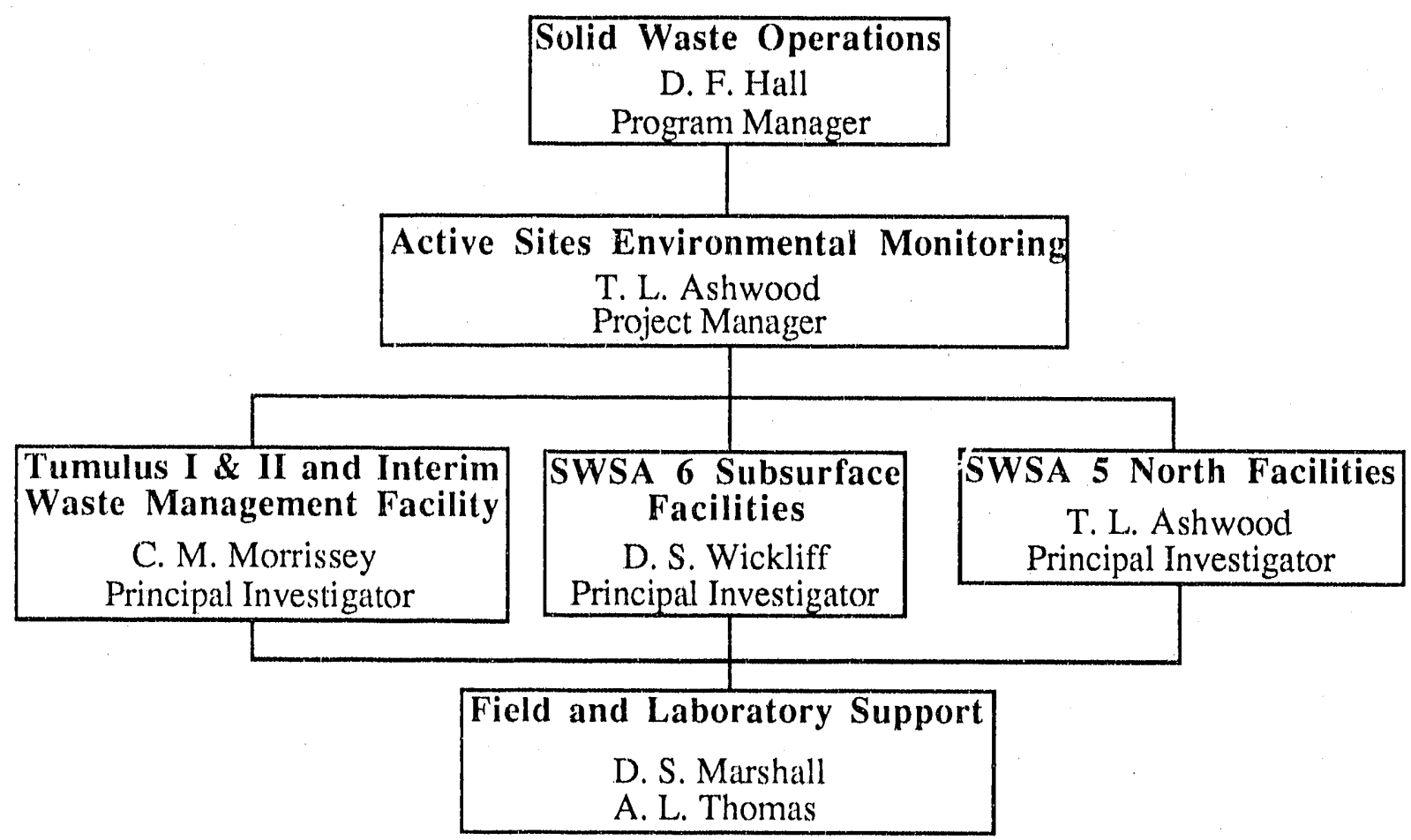

Fig. A.3. Organization of active sites environmental monitoring program. 


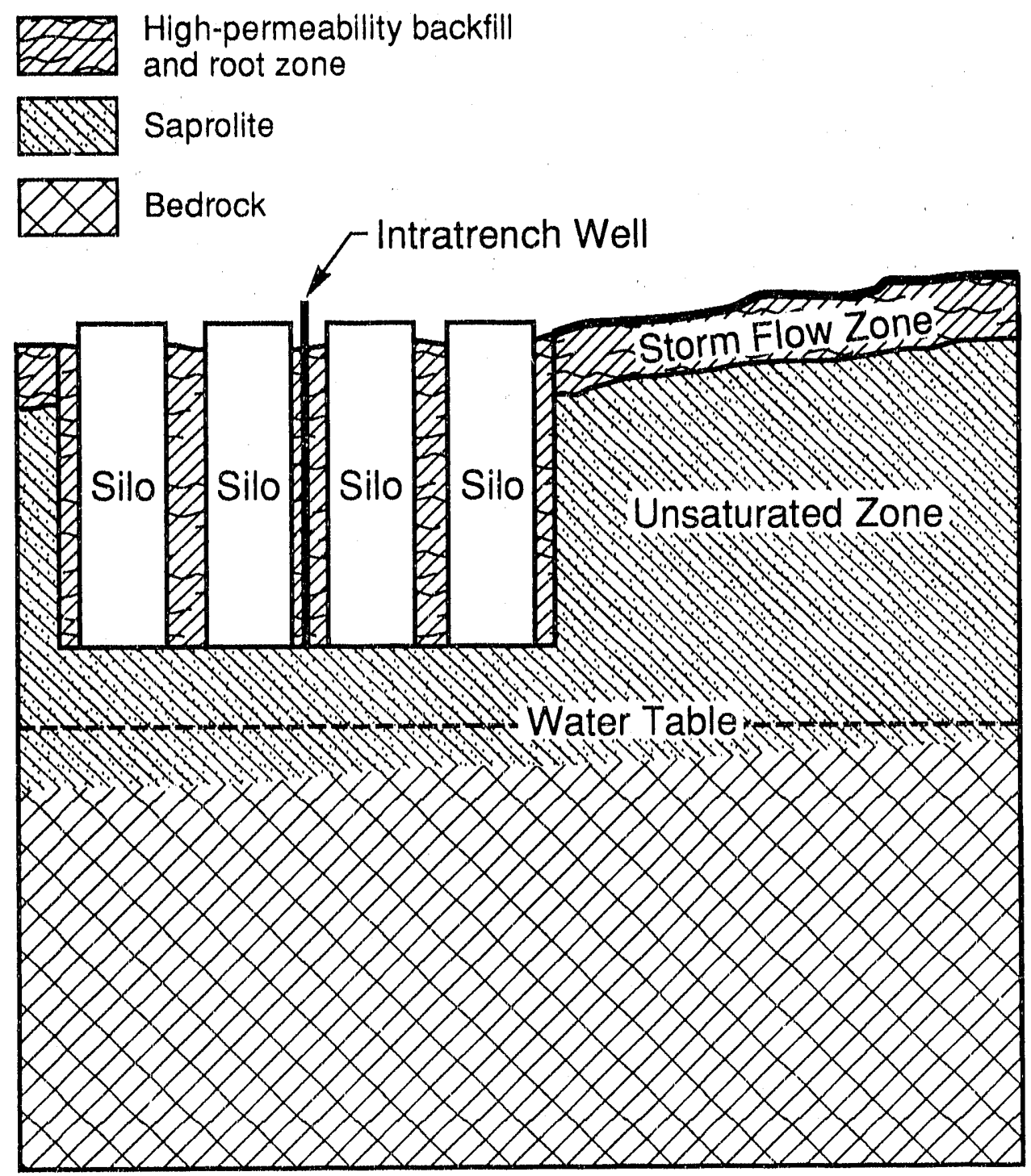

Fig. A.4. Typical cross section of low-level waste disposal trench. 


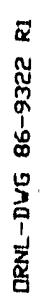

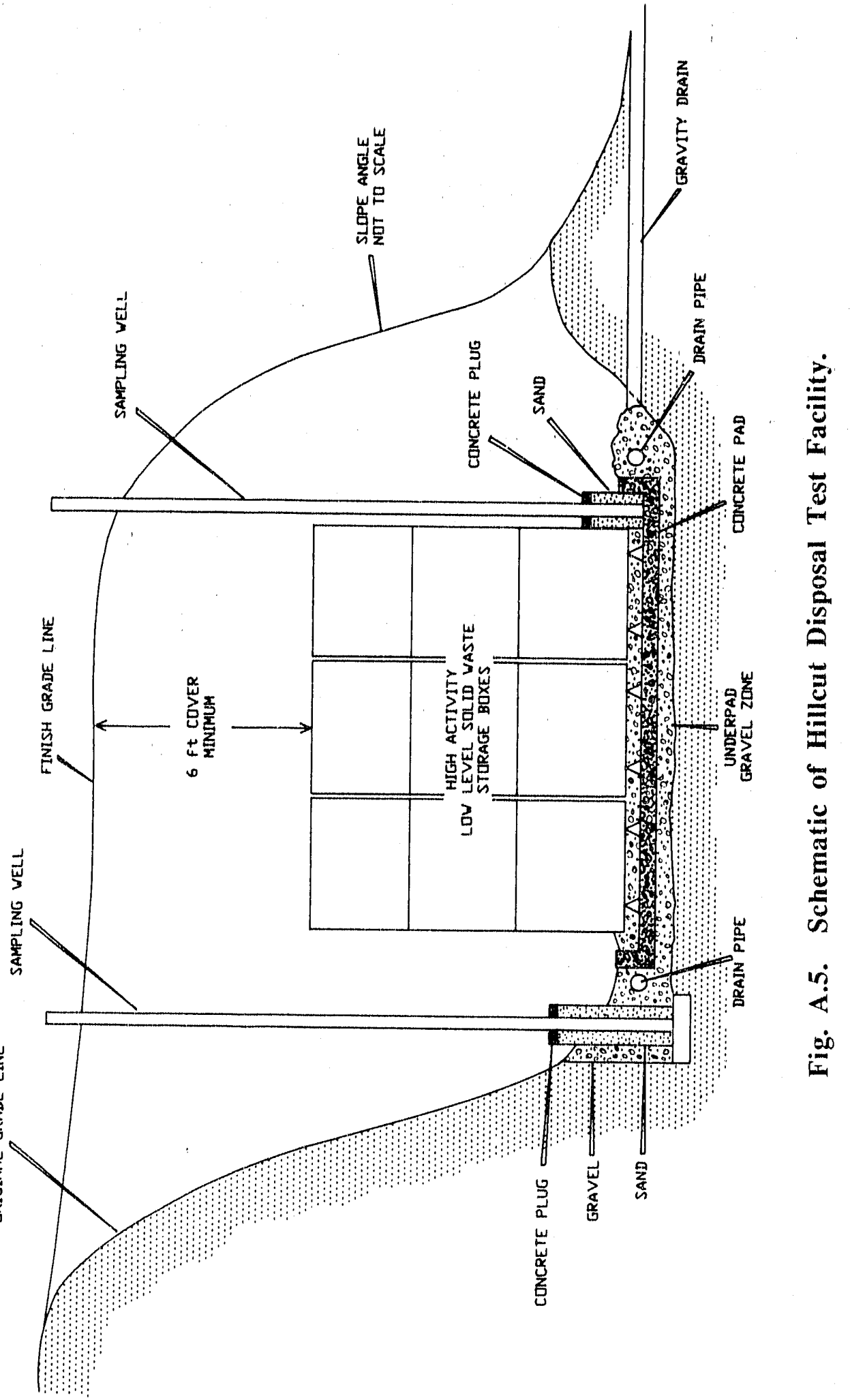




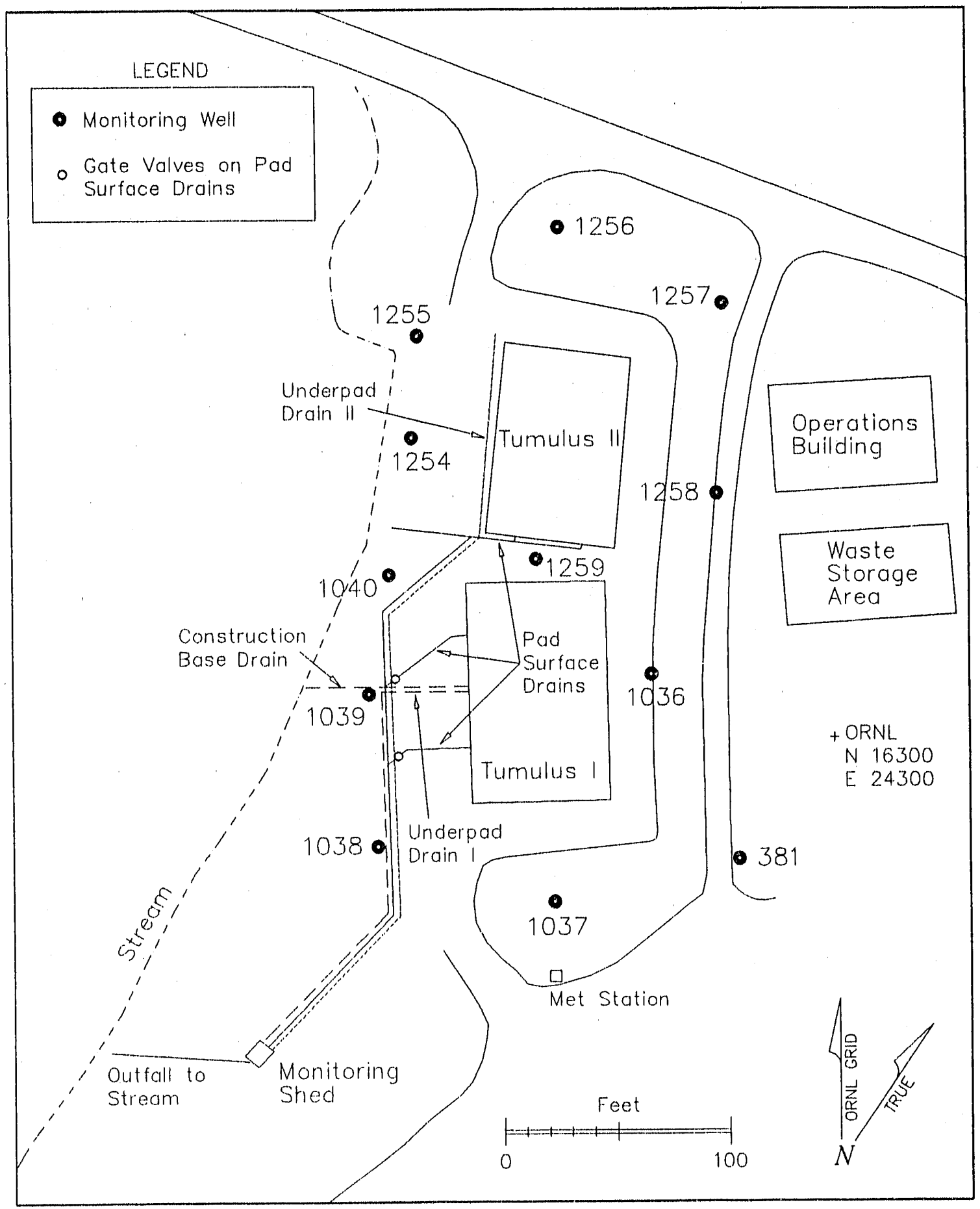

Fig. A.6. Tumulus area in SWSA 6. 

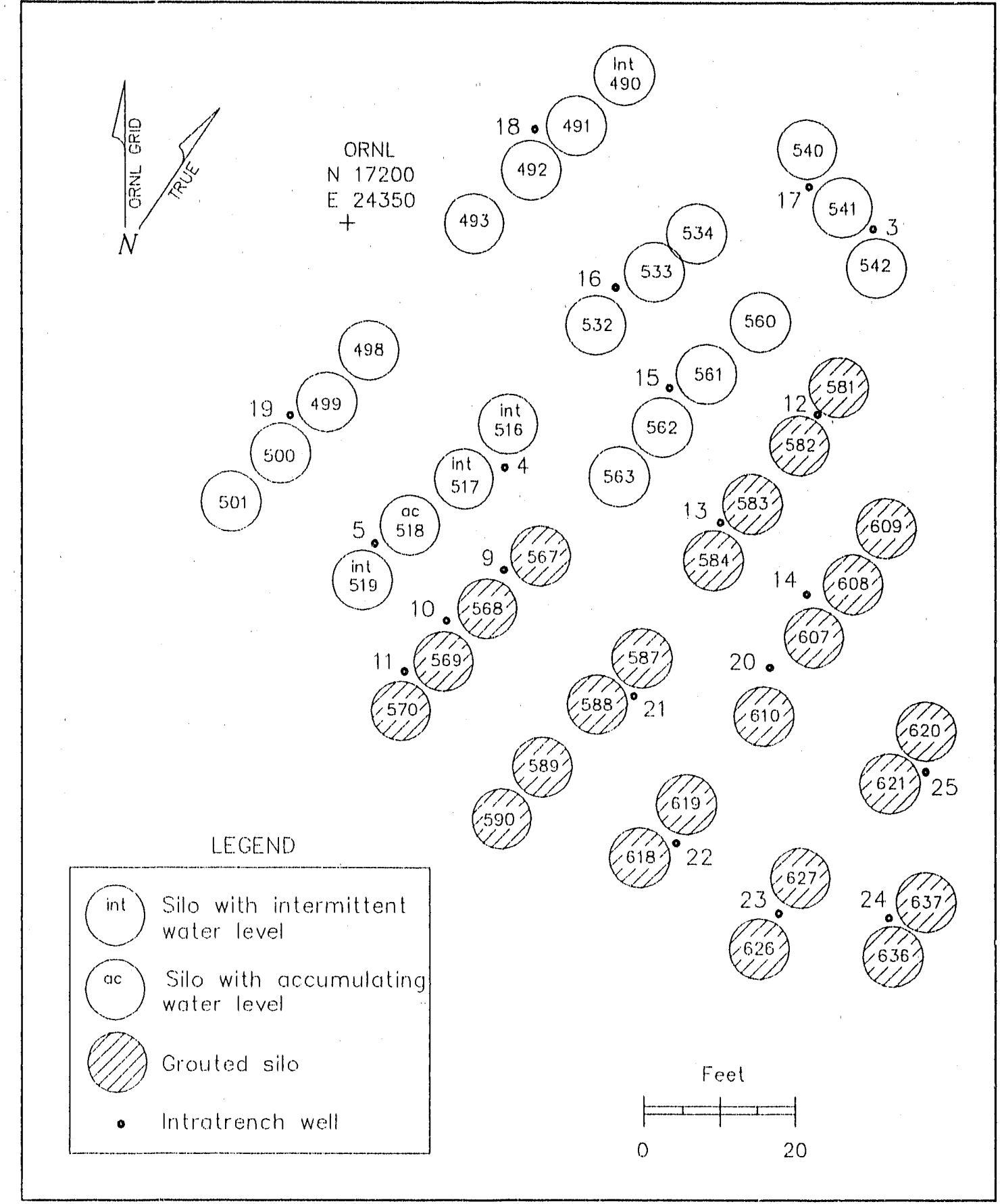

490

Fig. A.7. Locations of intratrench wells in SWSA 6 low-activity silos area north. 
ORNL-DWG 91-14600

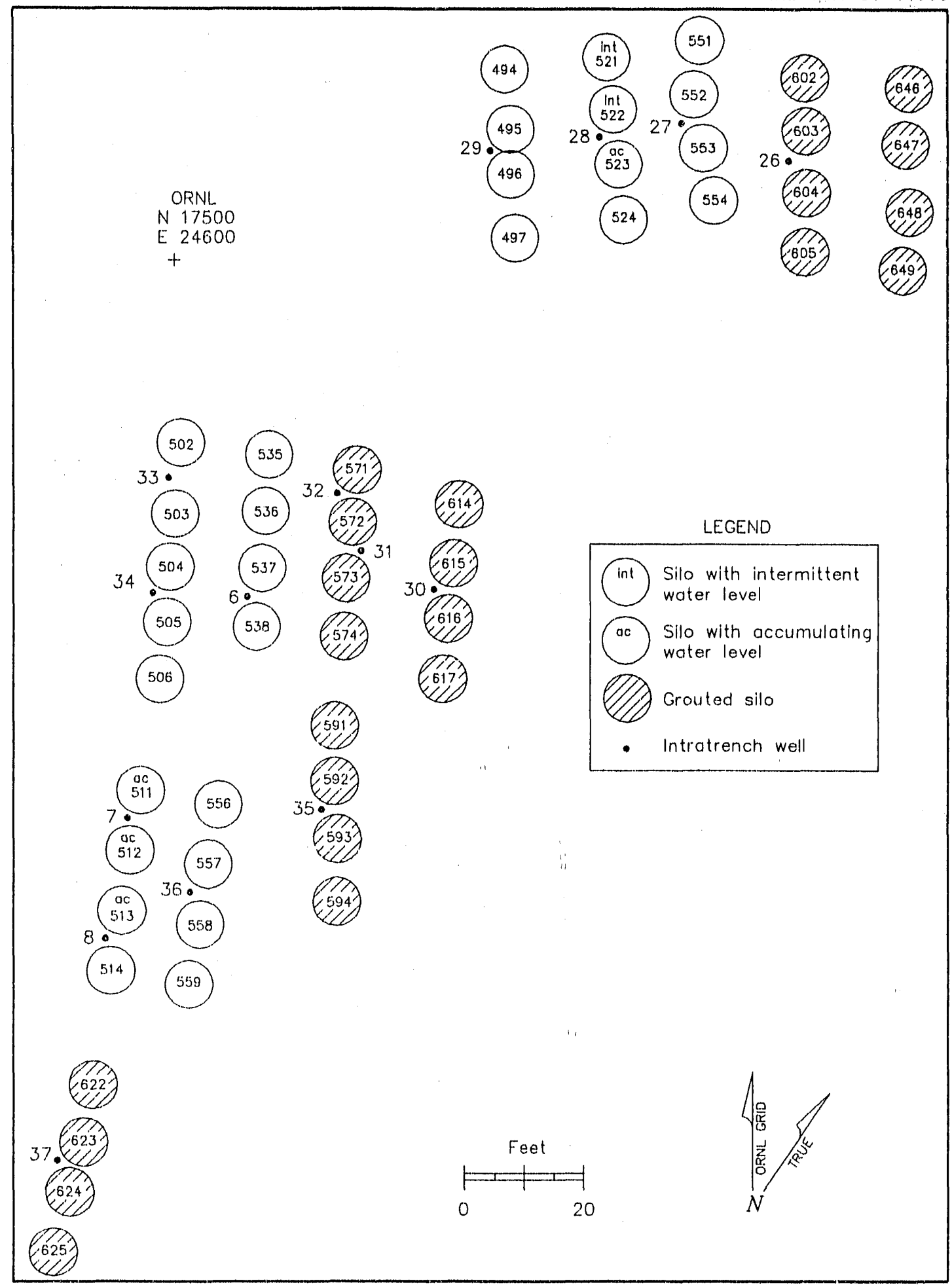

Fig. A.8. Locations of intratrench wells in SWSA 6 high-activity silos area. 


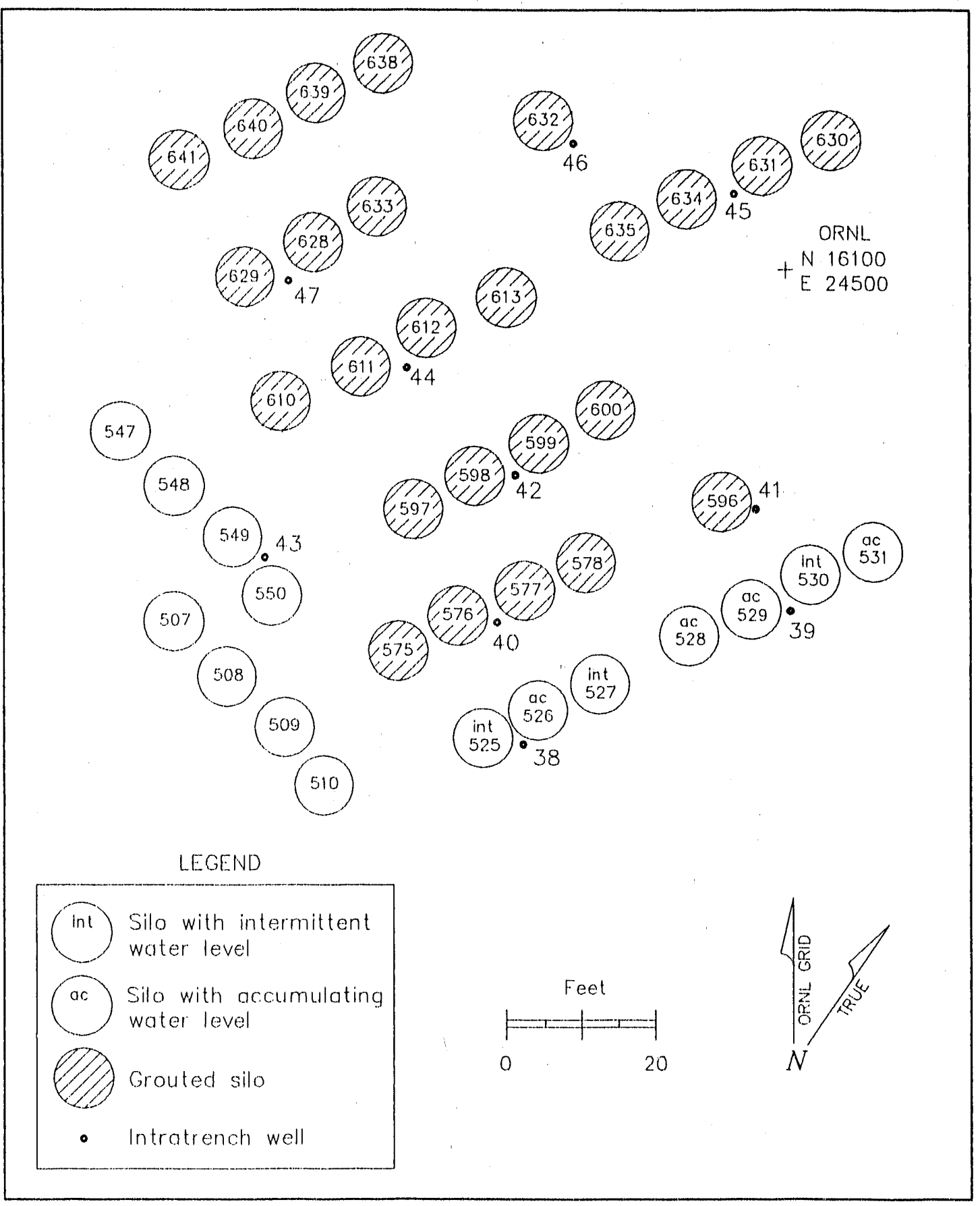

Fig. A.9. Locations of intratrench wells in SWSA 6 low-activity silos area south. 


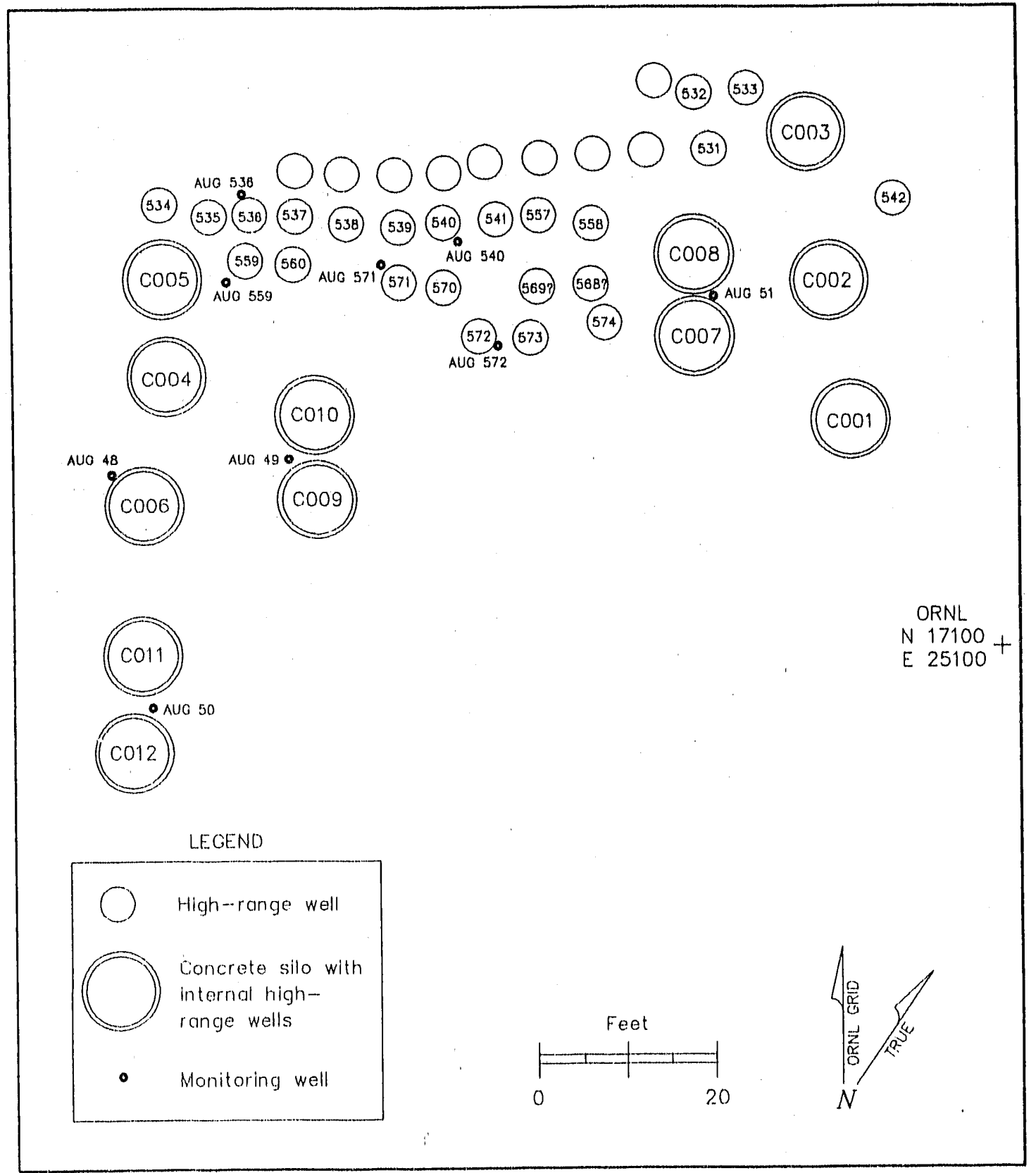

Fig. A.10. Locations of new wells near SWSA 6 high-range wells, fissile wells, and asbestos silos. 
APPENDIX B

TABLES 
B-3

Table B.1. Action levels for active sites environmental monitoring in SWSA 5 North and SWSA 6

\begin{tabular}{clc}
\hline \multicolumn{1}{c}{ Area } & Analyte & $\begin{array}{c}\text { Action level } \\
(\mathrm{Bc} / \mathrm{L})\end{array}$ \\
\hline SWSA 5 North & Gross beta & 2.0 \\
& 6()$^{2} \mathrm{Co}$ & 1.5 \\
SWSA 6 & $137 \mathrm{Cs}$ & 1.0 \\
& Gross alpha & 1.0 \\
& Gross beta & 5.0 \\
& $60 \mathrm{Co}$ & 1.5 \\
& $137 \mathrm{Cs}$ & 2.5 \\
\hline
\end{tabular}


Table B.2. Sample frequency and analytes for tumulus area in SWSA 6

\begin{tabular}{|c|c|c|c|c|}
\hline $\begin{array}{l}\text { Sample } \\
\text { location }\end{array}$ & Frequency & $\begin{array}{l}\text { Sample } \\
\text { size } F\end{array}$ & Preservation ${ }^{a}$ & Analytes $b$ \\
\hline Pad water & Episodicc & $\begin{array}{c}1 \mathrm{~L}^{d} \\
100 \mathrm{~mL}^{d} \\
100 \mathrm{~mL} \\
\geq 100 \mathrm{~mL}\end{array}$ & $\begin{array}{l}\mathrm{HNO}_{3} \\
\text { None } \\
\mathrm{H}_{2} \mathrm{SO}_{4} \\
\text { None }\end{array}$ & $\begin{array}{l}\text { gross } \alpha \text {, gross } \beta \text {, gamma scan } \\
\text { tritium } \\
\text { TOC } \\
\text { pH, specific conductance }\end{array}$ \\
\hline Underpad & Quarterly & $\begin{array}{c}1 \mathrm{Ld}^{d} \\
100 \mathrm{mLd} \\
\geq 100 \mathrm{~mL}\end{array}$ & $\begin{array}{l}\mathrm{HNO}_{3} \\
\text { None } \\
\text { None }\end{array}$ & $\begin{array}{l}\text { gross } \alpha \text {, gross } \beta \text {, gamma scan } \\
\text { tritium } \\
\text { pH, specific conductance }\end{array}$ \\
\hline $\begin{array}{l}\text { Construction } \\
\text { base drain }\end{array}$ & Quarterly & $\begin{array}{c}1 \mathrm{~L}^{d} \\
100 \mathrm{mLd} \\
\geq 100 \mathrm{~mL}\end{array}$ & $\begin{array}{l}\mathrm{HNO}_{3} \\
\text { None } \\
\text { None }\end{array}$ & $\begin{array}{l}\text { gross } \alpha \text {, gross } \beta \text {, gamma scan } \\
\text { tritium } \\
\text { pH, specific conductance }\end{array}$ \\
\hline
\end{tabular}

$a_{\mathrm{HNO}_{3}}=$ add $1 \mathrm{~mL}$ of $50 \% \mathrm{HNO}_{3} ; \mathrm{H}_{2} \mathrm{SO}_{4}=$ add $0.5 \mathrm{~mL}$ of $\mathrm{H}_{2} \mathrm{SO}_{4}$.

$b$ gross $\alpha=$ gross alpha screening analysis; gross $\beta=$ gross beta screening analysis; gamma scan $=$ complete spectrum of gamma emitting isotopes; TOC $=$ total organic carbon. All radionuclide analyses, except tritium, are counted for a sufficient time to reduce counting errors to $<0.5 \mathrm{~Bq} / \mathrm{L}$.

$c$ Episodic means immediately following each rain event that results in the accumulation of water on the pad.

d Two samples will be collected. One sample will be submitted to Analytical Chernistry Division, and the other sample will be retained as an archive until results from the first sample are received. 


\section{B-5}

Table B.3. Samples and analytes for groundwater wells around tumulus area and interim waste management facility in SWSA 6

\begin{tabular}{|c|c|c|c|c|}
\hline $\begin{array}{l}\text { Sample } \\
\text { Location }\end{array}$ & Frequency & $\begin{array}{l}\text { Sample } \\
\text { Size }\end{array}$ & Preservation ${ }^{a}$ & Analytesh \\
\hline Wells & Quarterly & $\begin{array}{c}1 \mathrm{~L}^{c} \\
100 \mathrm{mLc} \\
100 \mathrm{~mL} \\
\geq 100 \mathrm{~mL}\end{array}$ & $\begin{array}{l}\mathrm{HNO}_{3} \\
\text { None } \\
\mathrm{H}_{2} \mathrm{SO}_{4} \\
\text { None }\end{array}$ & $\begin{array}{l}\text { gross } \alpha \text {, gross } \beta \text {, gamma scan } \\
\text { tritium } \\
\text { TOC } \\
\text { pH, specific conductance }\end{array}$ \\
\hline Wells $^{d}$ & Annually & $\begin{array}{l}500 \mathrm{~mL} \\
500 \mathrm{~mL} \\
40 \mathrm{~mL} \\
1 \mathrm{~L}\end{array}$ & $\begin{array}{l}\mathrm{HNO}_{3} \\
\text { None } \\
\text { Cool } \\
\mathrm{Cool}\end{array}$ & $\begin{array}{l}\text { ICP metals } \\
\text { anions } \\
\text { volatile organics } \\
\text { semivolatile organics }\end{array}$ \\
\hline
\end{tabular}

${ }^{a} \mathrm{HNO}_{3}=$ add $1 \mathrm{~mL}$ of $50 \% \mathrm{HNO}_{3} ; \mathrm{H}_{2} \mathrm{SO}_{4}=$ add $0.5 \mathrm{~mL}$ of $\mathrm{H}_{2} \mathrm{SO}_{4}$; Cool means refrigerate to $4^{\circ} \mathrm{C}$. All samples are to be filtered through a $0.45-\mu \mathrm{m}$ filter prior to other preparation steps.

${ }^{b}$ gross $\alpha=$ gross alpha screening analysis; gross $\beta=$ gross beta screening analysis; gamma scan $=$ complete spectrum of gamma emitting isotopes; $\mathrm{TOC}=$ total organic carbon; ICP = inductively coupled plasma spectrometry. All radionuclide analyses, except tritium, are counted for sufficient time to reduce counting errors to $<0.5 \mathrm{~Bq} / \mathrm{L}$.

$c$ Two samples will be collected. One sample will be submitted to Analytical Chemistry Division, and the other sample will be retained as an archive until results from the first sample are received.

${ }^{d}$ Six randomly chosen wells around the tumulus pads and the three new wells at the IWMF area. 
Table B.4. Sample frequency and analytes for interim waste management facility in SWSA 6

\begin{tabular}{|c|c|c|c|c|}
\hline $\begin{array}{l}\text { Sample } \\
\text { Location }\end{array}$ & Frequency & $\begin{array}{l}\text { Sample } \\
\text { Size P }\end{array}$ & Preservation ${ }^{a}$ & Analytes $b$ \\
\hline Pad water & Episodic & $\begin{array}{c}1 \mathrm{Ld} \\
100 \mathrm{mLd} \\
100 \mathrm{~mL} \\
\geq 100 \mathrm{~mL}\end{array}$ & $\begin{array}{l}\mathrm{HNO}_{3} \\
\text { None } \\
\mathrm{H}_{2} \mathrm{SO}_{4} \\
\text { None }\end{array}$ & $\begin{array}{l}\text { gross } \alpha \text {, gross } \beta \text {, gamma scan } \\
\text { tritium } \\
\text { TOC } \\
\text { pH, specific conductance }\end{array}$ \\
\hline Underpad & Episodic & $\begin{array}{c}1 \mathrm{~L}^{d} \\
100 \mathrm{~mL}^{d} \\
\geq 100 \mathrm{~mL}\end{array}$ & $\begin{array}{l}\mathrm{HNO}_{3} \\
\text { None } \\
\text { None }\end{array}$ & $\begin{array}{l}\text { gross } \alpha \text {, gross } \beta \text {, gamma scan } \\
\text { tritium } \\
\text { pH, specific conductance }\end{array}$ \\
\hline French drain & Quarterly & $\begin{array}{c}1 \mathrm{~L}^{d} \\
100 \mathrm{~mL} \\
\geq 100 \mathrm{~mL}\end{array}$ & $\begin{array}{l}\mathrm{HNO}_{3} \\
\text { None } \\
\text { None }\end{array}$ & $\begin{array}{l}\text { gross } \alpha \text {, gross } \beta \text {, gamma scan } \\
\text { tritium } \\
\text { pH, specific conductance }\end{array}$ \\
\hline \multicolumn{5}{|c|}{$a_{\mathrm{HNO}_{3}}=$ add $1 \mathrm{~mL}$ of $50 \% \mathrm{HNO}_{3} ; \mathrm{H}_{2} \mathrm{SO}_{4}=$ add $0.5 \mathrm{~mL}$ of $\mathrm{H}_{2} \mathrm{SO}_{4}$} \\
\hline
\end{tabular}


Table B.5. Sample frequency and analytes for groundwater and surface water in SWSA 5 North

\begin{tabular}{|c|c|c|c|c|}
\hline $\begin{array}{l}\text { Sample } \\
\text { Location }\end{array}$ & Frequency & $\begin{array}{l}\text { Sample } \\
\text { Size }\end{array}$ & Preservation $^{a}$ & Analytes $b$ \\
\hline \multirow[t]{2}{*}{$\begin{array}{l}\text { Groundwater } \\
\text { wells }\end{array}$} & Quarterly & $1 \mathrm{~L}^{c}$ & $\mathrm{HNO}_{3}$ & $\begin{array}{l}\text { gross } \alpha \text {, gross } \beta, \text { transuranics, } \\
\text { gamma scan }\end{array}$ \\
\hline & $250 \mathrm{~mL}$ & None & tritium & \\
\hline $\begin{array}{l}\text { Surface } \\
\quad \text { streams }\end{array}$ & Quarterly & $1 \mathrm{~L}^{c}$ & $\mathrm{HNO}_{3}$ & $\begin{array}{l}\text { gross } \alpha, \text { gross } \beta, \text { transuranics, } \\
\text { gamma scan }\end{array}$ \\
\hline Seeps & Quarterly & $1 \mathrm{~L}^{c}$ & $\mathrm{HNO}_{3}$ & $\begin{array}{l}\text { gross } \alpha \text {, gross } \beta, \text { transuranics, } \\
\text { gamma scan }\end{array}$ \\
\hline
\end{tabular}

$a \mathrm{HNO}_{3}=$ add $1 \mathrm{~mL}$ of $50 \% \mathrm{HNO}_{3} ; \mathrm{H}_{2} \mathrm{SO}_{4}=$ add $0.5 \mathrm{~mL}$ of $\mathrm{H}_{2} \mathrm{SO}_{4}$.

${ }^{b}$ gross $\alpha=$ gross alpha screening analysis; gross $\beta=$ gross beta screening analysis; gamma scan $=$ complete spectrum of gamma emitting isotopes; transuranics $=241 \mathrm{Am}$ and ${ }^{244} \mathrm{Cm}$. All radionuclide analyses, except tritium, are counted for sufficient time to reduce counting errors to $<0.5 \mathrm{~Bq} / \mathrm{L}$.

$c$ If sufficient water is available, two samples will be collected. One sample will be submitted to Analytical Chemistry Division, and the other sample will be retained as an archive until results from the first sample are received. 


\section{APPENDIX C \\ PROGRAM SPECIFIC PROCEDURES}




\begin{tabular}{|ll|}
\hline Procedure ID: & TUM-01 \\
Revision No.: & 1 \\
Date of Revision: & 4 November 1991 \\
Date Implemented: & 4 November 1991 \\
\hline
\end{tabular}

PROCEDURE FOR COLLECTING SAMPLES OF TUMULUS PAD WATER

\author{
Prepared by: C. M. Morrissey \\ Geosciences Section
}

\title{
1.0 PURPOSE
}

This procedure documents the methods for collecting samples from water accumulating on the Tumulus I and Tumulus II pads. The purpose of the procedure is to provide consistent samples of water so that results may be compared between pads and over time. The procedure will also serve to train new project personnel.

\subsection{SCOPE}

This procedure addresses collection of water samples, preparation of the samples, and submission of the samples for analyses.

\subsection{EQUIPIMENT}

These materials are stored in the Tumulus monitoring shed or in the adjacent storage shed.

1. Five 1-L glass or plastic bottles for gross alpha, gross beta, and gamma scan.

2. Two glass bottles, at least $100 \mathrm{~mL}$ each, for total organic carbon.

3. Two glass or plastic bottles, at least $100 \mathrm{~mL}$ each, for tritium.

4. Two glass or plastic bottles, at least $100 \mathrm{~mL}$ each, for $\mathrm{pH}$ and specific conductance measurements (or a pH probe and meter and a specific conductance probe and meter).

5. Gloves.

6. Stainless steel widemouthed sampler and funnel.

7. Deionized water.

8. Acids: $50 \% \mathrm{HNO}_{3}$ and $50 \% \mathrm{H}_{2} \mathrm{SO}_{4}$.

9. Pipette and pipette tips for dispensing $0.5 \mathrm{~mL}$.

10. Labels for sample bottles.

11. Site visit checksheet and ball point pen.

12. Safety glasses. 


\subsection{PROCEDURES}

The procedure is identical for both pads.

1. Label sample bottle:; as follows:
a. Sample ID - for example, TUMII-012 (sample), TUMII-012A
(archive), TUMII-()13 (blank). Note that even numbers are for samples and odd numbers are for blanks.
b. Name of collector.
c. Date and time of collection.
d. Analysis requested.

2. Using the stainless steel sampler and funnel, collect enough water from any convenient spot on the pad to rinse the sampler and funnel. Return rinse water to a different location on the pad.

3. Collect more pad water with the sampler and add to appropriate bottles. Samples collected from each pad are as follows:
a. $1 \mathrm{~L}$ for gross alpha, gross beta, and gamma scan to be submitted to Analytical Chemistry Division (ACD);
b. $1 \mathrm{~L}$ for the same parameters to be stored as an archive;
c. $100 \mathrm{~mL}$ for total organic carbon analysis by ACD;
d. $100 \mathrm{~mL}$ for tritium analysis by $\mathrm{ACD}$;
e. $100 \mathrm{~mL}$ for a tritium archive;
f. $\quad \geq 100 \mathrm{~mL}$ for $\mathrm{pH}$ and specific conductance measurements in the lab unless such measurements are made directly on the pad.

4. If $\mathrm{pH}$ and specific conductance measurements are made directly on the pad, both meter/probe combinations should be checked and/or calibrated before use by following appropriate procedures. The probes may be dropped directly into the water on the pad and the rearings recorded on the site visit checksheets.

5. Collect a blank sample for gross radionuclide parameters by first rinsing the stainless steel sampler with deionized water located in the monitoring shed and then refilling the sampler with deionized water and collecting a 1-L sample.

6. Individual samples must be acidified as follows immediately after all samples are collected:
a. $1 \mathrm{~mL}$ of $50 \%$ nitric acid is added to each 1-L sample and archive for gross radiochemical analysis;
b. $\quad 0.5 \mathrm{~mL}$ of $50 \%$ sulfuric acid is added to each 100$)-\mathrm{mL}$ sample for total organic carbon.

7. If $\mathrm{pH}$ and specific conductance are measured using collected samples, measurements should be made as soon as possible.

8. Complete Analytical Services Request form and take samples to sample receiving room in Building 45())S. On the Analytical Services Request form, note that these samples are for the ASEMP and that the samples are to be counted for sufficient time to provide counting errors of $<0.5 \mathrm{~Bq} / \mathrm{L}$ on all analyses except tritium. The acidified archive samples are stored in the Tumulus monitoring shed and retained until the analytical data have been received. The unacidified tritium archive is stored in the refrigerator located in the monitoring shed until the analytical data have been received. 


\begin{tabular}{|ll|}
\hline Procedure ID: & TUM-(02 \\
Revision No.: & 1 \\
Date of Revision: & 4 November 1991 \\
Date Implemented: & 4 November 1991 \\
\hline
\end{tabular}

\title{
PROCEDURE FOR COLLECTING SAMPLES OF TUMULUS UNDERPAD DRAINS
}

\author{
Prepared by: C. M. Morrissey
}

Geosciences Section

\subsection{PURPOSE}

This procedure documents the methods for collecting samples of water draining from the underpad areas of Tumulus I and Tumulus II. The purpose of the procedure is to provide consistent samples of water so that results may be compared between pads and over time. The procedure will also serve to train new project personnel.

\subsection{SCOPE}

This procedure addresses collection of water samples, preparation of the samples, and submission of the samples for analyses.

\subsection{EQUIPMENT} shed.

These materials are stored in the Tumulus monitoring shed or in the adjacent storage

1. Stainless steel widemouthed sampler and funnel.

2. Five 1-L glass or plastic bottles for gross alpha, gross beta, and gamma scan.

3. Two glass or plastic bottles, at least $100 \mathrm{~mL}$ each, for tritium.

4. Two glass or plastic bottles, at least $100 \mathrm{~mL}$ each, for $\mathrm{pH}$ and specific conductance measurements.

5. Gloves.

6. Deionized water.

7. Acidi: $50 \% \mathrm{HNO}_{3}$.

8. Pipette and pipette tips for dispensing $0.5 \mathrm{~mL}$.

9. Labels for sample bottles.

10. Site visit checksheet and ball point pen.

11. Safety glasses. 


\subsection{PROCEDURES}

These samples will be collected periodically (at least once a quarter) as soon as possible after a rainfall of sufficient magnitude to produce adequate flow in the underpad drains.

\section{Tumulus I}

1. Label sample bottles as follows:
a. Sample ID: TUMI-012-UND (sample), TUMI-012A-UND (archive), TUMI-013-UND (blank). Note that even numbers are for sample and odd numbers are for blank.
b. Name of collector.
c. Date and time of collection.
d. Analysis requested.

2. Remove plug from underpad drain line and rinse sampler.

3. Collect sufficient underpad water for a 1-L sample for gross radionuclide analysis and a $1-\mathrm{L}$ archive, a $100-\mathrm{mL}$ tritium sample and a $100-\mathrm{mL}$ archive, and enough sample $(\geq 100 \mathrm{~mL}$ ) for $\mathrm{pH}$ and specific conductance measurements.

4. Collect a 1-L gross radionuclide blank sample of deionized water.

5. Individual samples must be acidified as follows immediately after all samples are collected: $1 \mathrm{~mL}$ of $50 \%$ nitric acid is added to each 1-L sample and archive for gross radiochemical analysis.

7. Specific conductance and $\mathrm{pH}$ measurements should be made as soon as possible.

8. Complete Analytical Services Request form and take samples to sample receiving room in Building 4500S. On the Analytical Services Request form, note that these samples are for the ASEMP and that the samples are to be counted for sufficient time to provide counting errors of $<0.5 \mathrm{~Bq} / \mathrm{L}$ on all analyses except tritium. The acidified archive samples are stored in the Tumulus monitoring shed and retained until the analytical data have been received. The unacidified tritium archive is stored in the refrigerator located in the monitoring shed until the analytical data have been received.

\section{Tumulus II}

1. Samples are collected from the water flowing out of the underpad drain pipe or from the underpad drain sump if insufficient water is flowing from the pipe.

2. Label sample bottles as follows:
a. Sample ID: TUMI-012-UND (sample), TUMI-012A-UND (archive), TUMI-013-UND (blank). Note that even numbers are for sample and odd numbers are for blank.
b. Name of collector.
c. Date and time of collection.
d. Analysis requested.

3. Collect sufficient underpad water for a $1-\mathrm{L}$ sample for gross radionuclide analysis and a $1-\mathrm{L}$ archive, a $100 \mathrm{~mL}$ tritium sample and a $100-\mathrm{mL}$ archive, and enough sample $(\geq 100 \mathrm{~mL}$ ) for $\mathrm{pH}$ and specific conductance measurements.

4. Collect a 1-L gross radionuclide blank sample of deionized water. 
5. Individual samples must be acidified as follows immediately after all samples are collected: $1 \mathrm{~mL}$ of $50 \%$ nitric acid is added to each 1-L sample and archive for gross radiochemical analysis.

7. Specific conductance and $\mathrm{pH}$ measurements should be made as soon as possible.

8. Complete Analytical Services Request form and take samples to sample receiving room in Building 4500S. On the Analytical Services Request form, note that these samples are for the ASEMP and that the samples are to be counted for sufficient time to provide counting errors of $<0.5 \mathrm{~Bq} / \mathrm{L}$ on all analyses except tritium. The acidified archive samples are stored in the Tumulus monitoring shed and retained until the analytical data have been received. The unacidified tritium archive is stored in the refrigerator located in the monitoring shed and retained until the analytical data have been received. 


\begin{tabular}{|ll|}
\hline Procedure ID: & TUM-03 \\
Revision No.: & 1 \\
Date of Revision: & 4 November 1991 \\
Date Implemented: & 4 November 1991 \\
\hline
\end{tabular}

\title{
PROCEDURE FOR SAMPLING TUMULUS I CONSTRUCTION BASE DRAIN
}

\author{
Prepared by: C. M. Morrissey \\ Geosciences Section
}

\subsection{PURPOSE}

This procedure documents the methods for collecting samples of water that drains from the construction base drain beneath the Tumulus I pad. The purpose of the procedure is to provide consistent samples of water so that results may be compared over time. The procedure will also serve to train new project personnel.

\subsection{SCOPE}

This procedure includes collection of water samples, preparation of the samples, and submission of the samples for analyses.

\subsection{EQUIPMENT} shed.

These materials are stored in the Tumulus monitoring shed or in the adjacent storage

1. Two 1-L glass or plastic bottles for gross alpha, gross beta, and gamma scan.

2. Two glass or plastic bottles, at least $100 \mathrm{~mL}$ each, for tritium.

3. One glass or plastic bottle, at least $100 \mathrm{~mL}$, for $\mathrm{pH}$ and specific conductance measurements.

4. Gloves.

5. Deionized water.

6. Acid: $50 \% \mathrm{HNO}_{3}$.

7. Pipette and pipette tips for dispensing $0.5 \mathrm{~mL}$.

8. Labels for sample bottles.

9. Safety glasses. 


\subsection{PROCEDURES}

Samples will be taken at least quarterly. Personnel must be prepared to collect samples soon after a rainfall or sufficient water will not be available.

1. Label sample bottles as follows:
a. Sample ID: TUMI-012-PWT (sample), TUMI-012A-PWT (archive), TUMI-013-PWT (blank). Note that even numbers are for sample and odd numbers are for blank.
b. Name of collector.
c. Date and time of collection.
d. Analysis requested.

2. Collect all samples by holding the appropriate container directly under the outfall pipe.

3. Collect samples and archives for gross radiochemical parameters and for tritium.

4. Acidify each 1-L gross radionuclide parameter sample with $1 \mathrm{~mL}$ of $50 \% \mathrm{HNO}_{3}$.

5. Complete Analytical Services Request form, and take samples to sample receiving room in Building 450)S. On the Analytical Services Request form, note that these samples are for the ASEMP and that the samples are to be counted for sufficient time to provide counting errors of $<0.5 \mathrm{~Bq} / \mathrm{L}$ on all analyses except tritium. 


\title{
PROCEDURE FOR COLLECTING FLOW-PROPORTIONAL SAMPLES OF INTERIM WASTE MANAGEMENT FACILITY PAD RUNOFF
}

\author{
Prepared by: C. M. Morrissey \\ Geosclences Section
}

\subsection{PURPOSE}

This procedure documents the methods for collecting samples of water draining from the pad at the Interim Waste Monitoring Facility (IWMF). The purpose of the procedure is to provide consistent samples of water so that results may be compared between pads and over time. The procedure will also serve to train new project personnel.

\subsection{SCOPE}

This procedure addresses collection of water samples, preparation of the samples, and submission of the samples for analyses.

\subsection{EQUIPMENT} shed.

These materials are stored in the Tumulus monitoring shed or in the adjacent storage

1. Three 1-L glass or plastic bottles for gross alpha, gross beta, and gamma scan.

2. Two glass bottles, at least $100 \mathrm{~mL}$ each, for total organic carbon.

3. Two glass or plastic bottles, at least $100 \mathrm{~mL}$ each, for $\mathrm{pH}$ and specific conductance measurements.

4. Gloves.

5. Deionized water.

6. Acids: $50 \% \mathrm{HNO}_{3}$ and $50 \% \mathrm{H}_{2} \mathrm{SO}_{4}$.

7. Pipette and pipette tips for dispensing $(0.5 \mathrm{~mL}$.

8. Labels for sample bottles.

9. Site visit checksheet and ball point pen.

10. Safety glasses. 


\subsection{PROCEDURES}

These samples should be collected following ench rainfall.

1. Check composite sumpler for sufficient (at least $1.5 \mathrm{~L}$ ) sample. If sufficient sample exists, turn composite sumpler power swltch and flow selector switch off.

2. Label sample bottles as follows:

a. Sumple ID: IWMF-CS-012 (sample), IWMF-CS-012A (archive), IWMF-CS-(013 (blank). Note that even numlsers are for sample and odd numbers are for blank.

b. Name of collecter.

c. Date and time of collection.

d. Analysis requested.

3. Rinse widemouthed sampler and funnel with delonized water.

4. Fill widemouthed sampler with deionized water.

5. Pour $1 \mathrm{~L}$ of deionized water into a 1-L bottle for a blank.

6. Rinse widemouthed sampler with a small amount of composite sample.

7. Fill widemouthed sampler with composite sumple.

8. Pour $1 \mathrm{~L}$ of sample into each of two 1-L sampling bottles (one for a sample to be sent to Analytical (Chemistry Division and one for an archive).

9. Pour sample for total organic carbon (TOC) into sampling bottle.

10. Pour sample for $\mathrm{pH}$ and specific conductance into sampling bottle.

11. Acidify samples as follows: $1 \mathrm{~mL}$ of $50 \% \mathrm{HNO}_{3}$ into gross alpha, gross beta, and garnma scan sample, archive and blank; $0.5 \mathrm{~mL}$ of $50 \% \mathrm{H}_{2} \mathrm{SO}_{4}$ into TOC sample. DO NOT ACIDIFY the simple for $\mathrm{pH} / \mathrm{specific}$ conductance.

12. Rinse composite sampler and widemouthed sampler with deionized water.

13. Turn flow selector switch to flow position and turn power switch on.

14. Complete Analytical Services Request form, and take samples to sample receiving room in Building 450()S. On the Analytical Services Request form, note that these samples are for the ASEMP and that the samples are to be counted for sufficient time to provide counting errors of $<.(0.5 \mathrm{~Bq} / \mathrm{L}$ on all analyses except tritium. 


\begin{tabular}{|ll|}
\hline Procedure ID: & TUM-()5 \\
Revision No.: & 1 \\
Date of Revision: & 4 November 1991 \\
Date Implemented: & 4 November 1991 \\
\hline
\end{tabular}

\title{
PROCEDURE FOR COLLECTING QUARTERLY SAMPLES FROM TUMULUS AND NEWLY INSTALLED IWMF MONITORING WELLS
}

\author{
Prepared by: C. M. Morrissey \\ Geosciences Section
}

\subsection{PURPOSE}

This procedure documents the methods for collecting samples of water from wells surrounding the tumulus pads and from selected wells at the Interim Waste Monitoring Facility (IWMF). The purpose of the procedure is to provide consistent samples of water so that results may be compared between pads and over time. The procedure will also serve to train new project persorinel.

\subsection{SCOPE}

This procedure includes calibration of the Hydrolab monitoring instrument, collection of water samples, preparation of the samples, and submission of the samples for analyses.

\subsection{EQUIPMENT}

Individual bladder pumps are installed in each well. The following equipment and supplies are needed to obtain samples from each well:

1. Pump controller and air compressor and appropriate air lines and connections.

2. One 1-L glass or plastic bottle for gross alpha, gross beta, and gamma scan.

3. One glass bottle, at least $100 \mathrm{~mL}$, for total organic carbon.

4. One glass or plastic bottle, at least $100 \mathrm{~mL}$, for tritium.

5, One 4()-mL vial for annual organic analysis from selected wells.

6. One 1-L amber glass bottle for semivolatile organics.

7. Two 500-mL plastic bottles for cation and anion samples (for annual analysis from selected wells).

8. Hydrolab and associated equipment.

9. Water level indicator.

10. Gloves.

11. Deionized water.

12. Acids: $50 \% \mathrm{HNO}_{3}$ and $50 \% \mathrm{H}_{2} \mathrm{SO}_{4}$. 
13. Pipette and pipette tips for dispensing $0.5 \mathrm{~mL}$.

14. Labels for sample bottles.

15. Site visit checksheet and ball point pen.

16. Safety glasses.

\subsection{PROCEDURES}

1. Calibrate Hydrolab for $\mathrm{pH}$, specific conductance, and dissolved oxygen in accordance with instructions in Hydrolab operating manual. This calibration must be performed each day that wells are sampled.

2. Measure initial depth to water with water level indicator and record on site visit checksheet.

3. Install Hydrolab in convenient location using in-line $0.45-\mu \mathrm{m}$ filter at Hydrolab inlet.

4. Purge well of at least one well volume while observing changes in $\mathrm{pH}$ and specific conductance.

5. Record $\mathrm{pH}$, specific conductance, temperature, oxidation-reduction potential, and dissolved oxygen.

6. Continue purging well until temperature, $\mathrm{pH}$, and specific conductance are stable (temperature change of $<0.5^{\circ} \mathrm{C}, \mathrm{pH}$ luctuating $\leq 0.2$ units, and specific conductance changing $\leq 5 \%$ ), until three well volumes have been purged, or until the well has been pumped dry.

7. Adjust flow for a long, slow, steady discharge, and collect samples into appropriate containers.

8. Samples collected quarterly are $1 \mathrm{~L}$ for gross radionuclide parameters and a $1-\mathrm{L}$ archive, $10.9 \mathrm{~mL}$ for total organic carbon, and $100 \mathrm{~mL}$ for tritium plus a $100 \mathrm{~mL}$ archive. Once a year samples will be collected for volatile $(40 \mathrm{~mL}$ ) and semivolatile (1 L) organics, cations $(50) \mathrm{mL}$ ), and anions $(500 \mathrm{~mL})$.

9. Record temperature, $\mathrm{pH}$, specific conductance, and depth to water at end of simpling.

10. Acidify and/or cool samples as follows:

a. add $1 \mathrm{~mL}$ of $50 \% \mathrm{HNO}_{3}$ to the $1-\mathrm{L}$ radionuclide parameter samples;

b. : add $0.5 \mathrm{~mL}$ of 5()$\% \mathrm{H}_{2} \mathrm{SO}_{4}$ to the $1(0)$-mL TOC samples;

c. cool both the volatile and semivolatile organic samples to $\sim 4^{\circ} \mathrm{C}$,

11. Complete Analytical Services Request form, and take samples to sample receiving room in Building 450()S. On the Analytical Services Request form, note that these samples are for the ASEMP and that the samples are to be counted for sufficient time to provide counting errors of $<(0.5 \mathrm{Bc} / \mathrm{L}$ on all analyses except tritium. 


\begin{tabular}{|ll||}
\hline Procedure ID: & IT-01 \\
Revision No.: & 1 \\
Date of Revision: & 4 November 1991 \\
Date Implemented: & 4 November 1991 \\
\hline
\end{tabular}

\title{
SUBSURFACE SWSA 6 LLW FACILITIES PROCEDURES
}

\author{
Prepared by: D. S. Wickllff \\ Geosciences Section
}

\subsection{PURPOSE}

This procedure documents the methods for collecting samples from intratrench wells and wells near auger holes, asbestos silos, and fissile wells in SWSA 6. The purpose of the procedure is to ensure consistency in collection of samples so that results can be compared among wells and over time. The procedure will also serve to train new project personnel.

\subsection{SCOPE}

Samples are collected quarterly from wells near LLW and asbestos silos, auger holes, and fissile wells in order to monitor disposal facilities for containment failure, leaching of wastes, and contaminant transport. Well monitoring also provides an indication of the existence of perched water conditions in the well. There are presently 44 intratrench wells next to LLW silos, 2 wells next to asbestos silos, 2 wells next to fissile wells, and 9 wells in the auger hole area. Samples from these wells are prepared for gamma, gross alpha, and gross beta analyses.

\subsection{EQUIPMENT}

1. Field logbook with Monitoring Summary Sheets.

2. Appropriate sample containers:

a. 250-mL, bottles

b. additional bottles for duplicates or for additional analyses, if clesired

3. Black permanent markers for labeling.

4. Paper towels.

5. Waste bag.

6. Plastic bags for samples.

7 Fleld clothing.

8 Rubber gloves.

9) GM detector. 


\section{C-16}

\subsection{PROCEDURES}

\subsection{Sample Collection}

Background radiation in the area should be monitored during sample collection for personnel safety. Avoid standing, walking, or leaning over auger and fissile wells.

1. Record date, time, and any other pertinent information in field logbook at initiation of sampling.

2. Locate well according to attached maps and label on well.

3. Wear rubber gloves and place blotter paper near well.

4. Take cap off well and pull nylon cord to retrieve weighted sample bottle from bottom of the well.

5. Carefully pour contents into $250-\mathrm{mL}$ bottle over the blotter paper to minimize spillage. Weighted sample bottles with $<50 \mathrm{~mL}$ of water should not be emptied, but left in the well.

6. Lower weighted sample bottle to the bottom, and allow any additional water to flow in. You can often hear and feel whether the well is dry by a thud or whether there is water remaining in the well by the buoyancy of the weighted bottle and the gurgling sound made as water fills the bottle.

7. Retrieve the bottle, repeat the process, and collect as much as $250 \mathrm{~mL}$ if possible.

8. Replace the weighted bottle in the well to collect water during the next quarter.

9. Label each $250 \mathrm{~mL}$ bottle carefully and clearly with the well identification number and date.

10. Collect used blotter paper and paper towels for proper waste disposal. Sample bottles should be placed in plastic bags and screened with GM detector before entering Building 1505 .

\subsection{Sample Preparation}

1. In the laboratory, samples should be filtered through $0.45-\mu \mathrm{m}, 45$-mm-diam filters so that all sediment from the sample is retained on the filter. Additional filters may be used if a filter clogs up before the complete sample has been filtered.

2. Save filters for ESD gamma scan in plastic 15 -cc petri dish.

3. Acidify filtered water sample with nitric acid to $\mathrm{pH}<2$.

4. Complete Analytical Services Request form, and take samples to sample receiving room in Building 4500S. On the Analytical Services Request form, note that these samples are for the ASEMP and that the samples are to be counted for sufficient time (up to $8 \mathrm{~h}$ ) to provide counting errors of $<0.5 \mathrm{~Bq} / \mathrm{L}$ on all analyses except tritium. 


\subsection{RESULTS AND RECORDS}

Estimate and record the approximate amount of water collected on the Monitoring Summary Sheet. Note any unusual conditions of the well or the water (extreme sediment or color, etc.) and record on the Monitoring Summary Sheet.

Record the number of filters used for each sample, the volume of sample, and any additional comments on the Monitoring Summary Sheet. 


\section{C-18}

\section{Subsurface SWSA 6 LLW Facilities \\ Monitoring Summary Sheet}

Collection date/time;

Well Volume

No. collected (mL)
No. of filters
Sample

Field comments vol. $(\mathrm{mL})$ Comments 


\begin{tabular}{|ll|}
\hline Procedure ID: & HDTF-01 \\
Revision No.: & 1 \\
Date of Revision: & 17 October 1990 \\
Date Implemented: & 17 October 1990 \\
\hline
\end{tabular}

\title{
FIELD SERVICE PROCEDURE FOR THE HILLCUT DISPOSAL TEST FACILITY
}

\author{
Prepared by: S. M. Gregory \\ Geosciences Section
}

\subsection{PURPOSE}

This procedure documents the routine service procedures for the Hillcut Disposal Test Facility (HDTF) site at SWSA 6. It will also serve as a guide for a fill-in site servicer or new project personnel. The procedure is used to minimize risk to the health and safety of project personnel and to guard against release of contaminants to the environment. The procedure will also serve to train new project personnel.

\subsection{SCOPE}

This proceciure includes those activities that involve routine servicing of the HDTF, winterizing the facility, sampling and emptying the tanks, and recording the data.

\subsection{EQUIPMENT}

\subsection{Weekly Service}

1. Special water level measuring device for wells

2. Ball point pen.

3. Data sheet.

4. Bucket (kept on site).

\subsection{Sampling and Transferring Water:}

1. 2-in.-diam flexible hoses (kept on site).

2. One clean $1-\mathrm{L}$ widemouthed sample bottle per tank being sampled.

3. One Analytical Services Request form.

4. Ball point pen and black permanent marker.

5. Nitric acid.

6. Catch pan (kept on site).

7. Bucket (kept on site).

8. Rubber gloves. 


\subsection{PROCEDURES}

\subsection{Weekly Service}

1. Measure the depth to water in the two wells on top of the hill. The wells are identified by well numbers, 1 and 2, marked on the riser with a black permanent marker.

a. Well 1 is the on-pad well. It almost always has some water in it; the level changes very little from week to week.

b. Well 2 is the off-pad well. It seldom has any water in it.

c. Remove the well caps and measure the depth to water in the wells. A special water level measuring device is used because it is capable of measuring water depths as shallow as $2 \mathrm{~mm}$.

d. Record the measurements on the data sheet in meters. The data sheet is a computer printout of the Lotus ${ }^{\circledR}$ spreadsheet where the data are stored. Check the current measurements against the previous weeks' measurements to see if they look reasonable. If they don't, make the measurements again.

e. Replace the well caps before leaving the well area.

2. Proceed to the tank area to measure the depths of water in the tanks.

a. Begin by making a visual inspection of the tank area. Look for any leaks in the tanks or piping.

b. Confirm that the white plastic stopcock at the end of the measuring assembly is closed.

c. Confirm that the cap is installed on the fitting for the 2-in. transfer hose. This is located between the 2 -in. ball valve and the stand pipe on the measurement assembly.

d. Water in the tanks are measured by opening the 2 -in. ball valves. This allows water from the tanks to flow into vertical clear plastic standpipes. Here the water levels can be viewed beside the scales attached to the standpipes. Open the ball valve from each tank and allow the water levels to equilibrate.

e. Tank 1 drains the pad and tank 2 drains the trench around the pad. Tank 1 will almost always have water in it and tank 2 rarely will. Determine the tank water levels using the scales on the standpipes, and record these values on the data sheet. Depths may be slightly less than the previous week because of water loss in the measurement process.

f. Close the 2 -in. ball valves.

g. Place the bucket, found at the site, under the white plastic stopcock at the end of the tank level measuring apparatus. Open the stopcock to drain the water in the standpipe into the bucket.

h. Confirm that the drain valve at the bottom of the holding tank is closed. Empty the contents of the bucket into the holding tank. It is especially important to drain the standpipe during cold weather to prevent freeze damage to the piping. 


\subsection{Winterizing the Site}

1. In November, have Plant and Equipment staff deliver bales of straw to the site and stack them around the tanks and around the piping up to the valves and measuring standpipes. This helps to reduce the chance of freeze damage.

\subsection{Sampling the Tanks and Transferring the Contents to Holding Tanks}

1. When a measuring tank becomes approximately two-thirds full, it should be sampled and the contents transferred to a holding tank. The tank fills fastest in the spring, so you may want to sample and transfer before a tank reaches two-thirds full if a lot of rain is forecast.

2. Before transferring the water from the measuring tank to the holding tank, a sample must be collected.

3. Open the 2-in, ball valve to the tank to be sampled.

4. After the water level stabilizes in the stand pipe, record the level in the tank, as described in step 2 of Sect. 4.1.

5. Label the sample bottle with a black permanent marker. The label should have a sample number and should say "groundwater" and "pH $<2$ ". The sample number should look like this: \#-YYMMDD-1 for the standard analysis. The \# is for the number of the tank that was sampled. The YYMMDD is the year, month, and day the sample was collected. The number " 1 " at the end indicates that it is the standard analysis: gross alpha, gross beta, and gamma scan. Example: 1-990130-1 for tank one, sample date 30 January 1999, standard analysis.

6. Put on a pair of rubber gloves as a precaution. Wear them for the whole sampling and transferring process.

7. Fill the sample bottle with tank water using the plastic stopcock at the end of the tank measuring apparatus.

8. Close the 2-in. ball valve.

9. Place the bucket under the stopcock. Open the stopcock to drain the contents of the measuring assembly into the bucket.

10. Close the stopcock.

11. Place the catch pan under the hose connection located between the 2 -in. ball valve and the riser pipe.

12. Remove the cap from the hose connection, making sure that any water remaining in the measuring assembly is caught by the catch pan.

13. The 2-in. transfer hose is left at the site, stretched from the measurement tank area to the holding tank. Connect the transfer hose to the fitting at the measuring tank.

14. Confirm that the drain valve at the bottom of the holding tank is closed.

15. Enupty the contents of the catch pan and the bucket into the holding tank through the port at the top of the tank.

16. Install the loose end of the transfer hose into the holding tank through the port at the top.

17. After confirming that the stop cock was closed in step 10 , open the 2 -in. ball valve. The water will begin transferring to the holding tank by gravity drain. 
18. After the transfer is complete, place the catch pan back under the hose connection at the tank measuring apparatus.

19. Close the 2 -in, ball valve.

20. Disconnect the hose connection from the measuring apparatus, making sure that any water left in the apparatus is caught by the catch pan. There shouldn't be any water left here; this is just a precaution.

21. Replace the cap to the hose connection on the tank measuring apparatus.

22. Raise the end of the hose at the measuring tank end to make sure that all water drains from the hose to the holding tank. This is especially important during freezing weather.

23. Remove the loose end of the hose from the holding tank.

24. If any water remains in the catch pan, pour it into the holding tank.

25. Install the plug in the port at the top of the holding tank.

26. If you brought nitric acid with you, add enough to the sample to bring the $\mathrm{pH}$ down to $\mathrm{pH}$ 2. If you need to, take the sample back to the lab to perform this step. Check the sample with pH paper to confirm that the $\mathrm{pH}$ is $\leq 2$.

27. Fill out an Analytical Services Request form for the sample and take it to room F50 in Building 4500S. For the standard analysis, request a gamma scan, gross alpha, and gross beta analyses. On the request form, fill in the deadline blank to make sure that yo'a get the results back before the next time the measuring tanks need to be tran sferred. A week from the submit date is typical but may need to be shortened during very rainy periods and may need to be lengthened during typically dry summer months.

28. In the event that the results are late in being received and more water needs to be transferred, there is a second holding tank at the site. If it becomes necessary to use this second tank, call Analytical Chemistry Division (4-7713 or 4-4528) to expedite the sample, and alert the project principal investigator immediately.

\subsection{Emptying the Holding Tanks}

1. Results from the sample analysis should be given to the project principal investigator, who will give instructions on how to dispose of the water. Determinations for disposal methods will be made according to the project contingency plan.

2. To date, no samples have indicated contamination warranting special treatment of the collected water; therefore the water has been released from the holding tanks to the environment where it infiltrates back into the groundwater.

3. If samples indicate that the water may be released to the environment per the project principal investigator:

a. Remove the plug to the port at the top of the holding tank. This will keep the tank from collapsing due to the vacuum created by water escaping from the bottom. Don't forget to do this step first; it will be difficult to remove the plug from the port after a vacuum has formed.

b. Open the drain valve at the bottom of the tank.

c. Allow all of the tank contents to drain.

d. Close the drain valve.

e. Reinstall the plug in the port at the top of the tank. 
4. In the event that contamination shows up in a sample that exceeds the limits for this type of disposal as outlined in the project contingency plan, follow the directions of the project principal investigator for disposal and for future operation of the site.

\subsection{RESULTS AND RECORDS}

1. There are two spreadsheets for this project; one for well and tank level measurements, and one for analytical results.

2. After each week's well and tank level measurements are taken, add the values to the Lotus ${ }^{\circledR}$ spreadsheet titled SWSA6HSE.WK1.

a. Add the values to the appropriate columns.

b. There are two columns for computing the tank volumes from the tank levels. Using Lotus ${ }^{\circledR}$ macros, compute these volumes as follows:

i. There are two macros per tank; the cholce depends on the tank level (example: use macro A for tank 1 when the level is less than $12 \mathrm{~cm})$.

ii. Instructions on how to choose the correct macro are given in the titles portion of the spreadsheet.

iii. To operate the macros, move to the volume column of the spreadsheet for the tank that you want to calculate the volume for.

iv. Move the cell pointer to the cell beside the tank level that you wish to use for your volume calculation.

v. Invoke the macro by hitting the Alt key and the letter designation for the proper macro (Alt-A for the above example).

c. Save the spreadsheet before exiting Lotus, ${ }^{\circledR}$ and save the field notes with the original level data in a project file.

3. When analytical results are received, enter them into the Lotus ${ }^{\circledR}$ spreadsheet named HCWQ-2.WK1.

a. Enter the values from the analytical data sheet along with their error ranges into the spreadsheet.

b. Save the spreadsheet before exiting Lotus, ${ }^{\circledR}$ and save the original analytical data sheet in a project file. 


\begin{tabular}{|ll|}
\hline Procedure ID: & SWSA5N-01 \\
Revision No.: & 1 \\
Date of Revision: & 4 November 1991 \\
Date Implemented: & 4 November 1991 \\
\hline
\end{tabular}

\section{PROCEDURE FOR GROUNDWATER SAMPLING IN SWSA 5 NORTH}

Prepared by:

D. S. Wickliff

Geosciences Section

and

T. L. Ashwood

Environmental Biotechnology Section

\subsection{PURPOSE}

This procedure documents the methods for collecting samples from groundwater wells in SWSA 5 North. The purpose of the procedure is to provide consistent samples of water so that results may be compared between wells and over time. The procedure will also serve to train new project personnel.

\subsection{SCOPE}

This procedure addresses measurement of water levels, collection of water samples, preparation of the samples, and submission of the samples for analyses.

\subsection{EQUIPMENT}

See specific equipment requirements in procedure subsections 4.1.1, 4.2.1.1, and 4.2.2.1.

\subsection{PROCEDURES}

\subsection{Water Level Measurements}

\subsubsection{Equipment}

1. Electronic water level indicator with measurements in feet (e.g., M scope).

2. Field logbook.

3. Black permanent pen.

4. Protective clothing--see Project Safety Summary.

5. Radiation monitors:

a. Pocket visual dosimeter.

b. GM detector. 


\subsubsection{Procedures}

The following steps should be conducted at each well prior to sumpling or at any other time that water level measurements are needed.

1. Record well number, date, time, and any other pertinent information in fleld logbook,

2. Locate reference mark at top of well casing.

3. Lower probe of water level indicator into well. When the alarm sounds, stop lowering the probe. Pull up on the probe until alarm no longer sounds; then lower the probe again slowly, stopping at the instant the alarm sounds.

4. Using the mark on top of the casing as the reference point, determine the depth on the tape to the nearest $0.01 \mathrm{ft}$. Repeat the procedure to verify measurement. Record the measurement as depth to water in field logbook.

5. Rinse the probe and any portion of the tape that contacted well water with deionized water. The rinse water should be placed in the purge water drums at each well. If no drum is available, the rinse water should be collected and disposed of as liquid low-level waste.

\subsection{Groundwater Sampling}

Groundwater samples will be collected quarterly for radionuclide analysis (gross alpha, gross beta, and a gamma scin). In addition, a sample for tritium analysis will be collected from each of the wells. Prior to sample collection, wells will be purged to ensure that the sample is representative of the groundwater.

\subsubsection{Well Purging}

\subsubsection{Equipment}

1. Pump and associated equipment:

a. Portable Waterra pump for all wells except 516.

b. Gasollne powered compressor and controller for dedicated bladder pump in well 516.

2. Extension tubing for each well. This tubing is marked for each well and may be reused.

3. Screwdriver (flat), hose clamps, and fittings to connect tubing to Hydrolab and to extension tubing.

4. Hydrolab II.

5. Stop watch.

6. Container of known volume.

7. Calculator.

8. Field logbook.

9. Black permanent pen.

10. Protective clothing--see Project Safety Summary.

11. Rudiation monitors:

a. Pocket visual dosimeter. 
b. GM detector.

11. Appropriate containers for waste.

12. Drum(s) for purge water. These drums shotid be on slte at each well. If they are not, crall Solld Waste Operiations to have drums delivered.

\subsubsection{Procedures}

1. Measure groundwater level as indicated In Sect, 4.1, and calculate the volume of water in the well by using the formula on the Groundwater Monitoring Summary Sheet. Table 1 provides a list of well depths, dlameters, and typical depths to water and well volumes. Compare your calculated well volume with the typical volume. If there is a large discrepancy, review your calculation and/or your depth to water measurement.

Table, 1. Groundwater monitoring information for SWSA 5 North

\begin{tabular}{ccccc} 
Well & Total well depth & Depth to water & Approx, well \\
Well & diam. & from $M P(t$ & in $11 / 90$ & volume in $11 / 90$ \\
no. & $(\mathrm{in})$, & $(\mathrm{ft})$ & $(\mathrm{gall})$ & \\
\hline
\end{tabular}

Wells that should be pumped dry

$\begin{array}{rrrrr}514 & 6 & 30.4 & 20.81 & 14 \\ 517 & 6 & 32.4 & 14.35 & 27 \\ 518 & 6 & 31.6 & 17.92 & 20 \\ 519 & 6 & 25.6 & 13.53 & 18 \\ 521 & 4 & 87.6 & 25.63 & 40 \\ 522 & 6 & 69.2 & & \\ 523 & 6 & 11.2 & 44.97 & 36 \\ 524 & 3 & 12.0 & 5.43 & 2 \\ 525 & 3 & 29.4 & 3.84 & 3 \\ 716 & 6 & 16.24 & 19 \\ & 2 & 100.7 & 6.52 & 15\end{array}$

Wells that should be pumped for 1--3 volumes

$\begin{array}{rrrrr}513 & 6 & 20.6 & 8.5 & 18 \\ 516 & 4 & 26.8 & 15.42 & 7 \\ 520 & 6 & 24.6 & 1.57 & 34 \\ 708 & 2 & 18.0 & 4.12 & 2 \\ 715 & 2 & 41.0 & 14.9 & 4\end{array}$

Water level measurement only'

$\begin{array}{llll}562 & 2 & 150.0 & 45.73\end{array}$

" $\mathrm{MP}=$ measurement point.

2. Connect the Waterra pump to the dedicated hose in well, and connect well tubing to extension tubing. Connect extension tubing to drum, For well 516, connect the controller to the compressor and dedicated tubing in the well and comnect extension tubing to Hydrolab. 
3. Begin pumping and record the time of Indtation on the Groundwater Monitoring Summonry sheet. Determine rate of evacuation by timing the filling of the container of known volume. Record the pumping rate on the Groundwater Monitoring Summary Sheet. Empty the contulner into the purge water drum.

4. Note the appearunce of the water (color, cloudy, clear, etc.), and record the data on the Groundwater Monitoring Summary Sheet.

5. Conthue pumplng until the well is dry, until three well volumes have been removed, or untll field puramelers have stabillzed as follows.

il. For wells 514, 517, 518, 519, 521, 522, 523, 524, 525, and 716, pump wells until they are dry.

b. For wells $513,516,52($ ), and 708 , pump three well volumes or pump at least one well volume and then pumip until temperature, $\mathrm{pH}$, and specific conductance have stabilized (temperature $\pm 0.5^{\circ} \mathrm{C}, \mathrm{pH} \pm 0.1$ unit, specific conductunce $\pm 5 \%$ ).

6. All purge water is to be collected and drummed. The water will be kept until andlytical resulss are avallable. If the analytical results indicate that the water contains radionuclicles above the ASEMP action levels, contact Solid Waste Operations for disposal of the water; otherwise the drums may be emptied on site.

\subsubsection{Sample Collection}

\subsubsection{Equipment}

1. Pump and associated ecjuipment:

i. Portable Waterra pump for all wells except 516.

b. Gasolline-powered compressor and controller for dedicated bladder pump in well 516.

2. Extension tubing for each well. This tubing is marked for each well and may be reused.

3. Screwdriver (flat), hose clamps, and fittings to connect tubing to Hydrolab and to extension tubing.

4. Hydrolub II.

5. In-line filters.

6. Appropriate sumple containers:

a. I-L botlles for gross alpha, gross beta, and gamma scan.

b. $125 \mathrm{ml}$ bottles for tritlum.

7. Black permanent markers for labeling.

8. Paper towels.

9. Waste bags.

10. Plastic bags for samples.

\subsubsection{Procedures}

Sampling should be done us soon as possible after the well has been evacunted. Allow I day for recovery of those wells that were pumped to dryness. 
1. If not alrendy connected, connect pump as described in Sect, 4,2,1,2, Connect extension tubing to the Hydrolab and to the in-line filter making sure that water flow will be in the difection indicated by the arrow on the fliter. Direct the discharge of the filter to the purge willor drum.

2. Adjust the pump to provide a stendy stream of water from the filter dischurge.

3. Before collecting simples, measure the pH, specifle conductance, und temperature of the well water. Record the information in fleld logbook.

4. From each well collect one sample in a 1.L bottle for gross alpha and beta analyses, and gamma sean) and one sample in the $125-\mathrm{mL}$ bottle (for tritium analysis).

5. Label ench bottle carefully and clearly with the well number, date, time, and preservative (see step 8). Enter information in the field logbook.

6. Sample bottles should be placed in plastic bags and screened with GM detector before returning to Bullding $15(0) 5$.

7. Rinse the Hydrolab and extension tubing with deionized water. Collect rinse water in purge waler' dr'um.

8. After returning to the lab, add $1 \mathrm{~mL}$ of $50 \% \mathrm{HNO}_{3}$ to samples in $1-\mathrm{L}$ bottles. Do not add acid to the tritlum samples.

9. Complete Analytical Services Recuest form and take samples to sample receiving room in Building 450)S. On the Analytical Services Request form, note that these samples are for the ASEMP and that the samples are to be counted for sufficient time to provide counting errors of $<() .5 \mathrm{~Bq} / \mathrm{L}$ on all analyses except tritium.

\subsection{RESULTS AND RECORDS}

As noted in Sect. 4.0, all data are to be recorded in the field logbook or on the Groundwater Monitoring Summary Sheet. After completion, each Groundwater Monitoring Summary Sheet is to be glued into the field logbook on a separate page. In addition, a copy of all Analytical Services Request forms should be glued into the field logbook. Analytical results are to be given to the principal investigator. 


\section{GROUNDWATER MONI'TORING SUMMARY SHEET}

Well Number:

Date:

\section{Well Casing Volume Determination}

A. Depth of well: $\mathrm{ft}$

B. Mensured depth to water: $\mathrm{ft}$

C. Height of water column (A - B): $\mathrm{ft}$

D. Casing diameter: in

Volume $=\mathrm{C} \times(1.47$ for $6 \mathrm{in}$. Casing diameter $)=$ (0.65 for 4. in. Casing diumeter) gal

(0.37 for 3 -in. Casing diameter)

(0.16 for 2 -In. Casing diameter)

\section{Well Evacuation}

Initiation time

Evacuation rate: $\mathrm{gal} / \mathrm{min}(1 \mathrm{gal}=3.785 \mathrm{~L})$

Messurement Villue 1 Value 2 Value? Value 4 Value 5

Date:

Time:

$\mathrm{pH}$ :

Temperiture:

Specific conductance:

Gallons evacuated;

Well volumes purged:

\section{Sample Collection}

Date:

Time:

\section{Comments and Observations}

Appearance of water at initiation:

Appearance of water at completion:

Comments: 


\begin{tabular}{|ll|}
\hline Procedure ID: & SWSA5N-02 \\
Revision No.: & 0 \\
Date of Revision: & 4 November 1991 \\
Date Implementer: & 4 November 1991 \\
\hline
\end{tabular}

PROCEDURE FOR SURFACE WATER SAMPLING IN SWSA 5 NORTH

Prepared by:

T. L. Ashwood

Environmental Biotechnology Section

and

D. S. Wickliff

Geosciences Section

\subsection{PURPOSE}

This procedure documents the methods for collecting samples from seeps and streams around SWSA 5 North. The purpose of the procedure is to provide consistent samples of water so that results may be compared among wells and over time. The procedure will also serve to train new project personnel.

\subsection{SCOPE}

This procedure addresses collection of water samples, preparation of the samples, and submission of the samples for analyses.

\subsection{EQUIPMENT}

1. Field logbook.

2. Black permanent marker.

3. Protective clothing--see Project Safety Summary.

4. Chest waders for bank seeps or rubber boots for stream samples.

5. Radiation monitors:

a. Pocket visual dosimeter.

b. GM detector.

6. 1-L and 250-mL sample bottles.

7. Metal spatulas.

7. Paper towels.

8. Waste bags.

9. Plastic bags for samples. 


\subsection{PROCEDURES}

Sample locations are indicated on the map of the area in the program plan, and these locations are marked in the field by flags. If flags are missing, contact either D. S. Wickliff or T. L. Ashwood for exact locations. Bank seeps may be located by measuring in a downstream direction from the south bank of the North Tributary. Seeps are identified by their distance, in meters, downstream from this point.

1. If water is present at the stream locations, dip a $1-\mathrm{L}$ bottle into the water and fill as far as possible, being careful not to stir up sediment. Finish filling 1-L bottle by dipping 250-mL bottle inte water and pouring contents into 1- $\mathrm{L}$ bottle.

2. If water is present at bank seeps, push a metal spatula into the bank at the seep to provide a spout for the water. After the water has cleared, hold $250-\mathrm{mL}$ bottle under the spout until full.

3. If water is present at other seeps, fill a $1-\mathrm{L}$ sample bottle by repeatedly submerging a $250-\mathrm{mL}$ bottle in the seep and pouring the contents into the 1-L bottle. Be careful to minimize the amount of sediment suspended by this process.

4. Wipe off excess moisture from the outside of the sample bottles in the field. Scan the bottles with the GM detector before taking them into Building 1505. If the bottles read more than 50 counts per minute above background, contact Health Physics. Dispose of the paper towels in the waste bags as solid low-level waste.

5. After returning to the lab in Building 1505 , filter each sample through $0.45-\mu \mathrm{m}$ filters and into clean sample bottles. Mark the filters with the number of the sample, and place the filters in a 15-cc petri dish. Submit this dish to the ESD counting room for an overnight gamma scan.

6. Complete Analytical Services Request form, and take samples to sample receiving room in Building 450()S. On the Analytical Services Request form, note that these samples are for the ASEMP and that the samples are to be counted for sufficient time to provide counting errors of $<0.5 \mathrm{~Bq} / \mathrm{L}$ on all analyses except tritium.

\subsection{RESULTS AND RECORDS}

The date, location, time, and any unusual conditions are to be recorded in the field logbook for each sample. For each sample, the volume of sample filtered and the number of filters required are to be recorded in the field logbook. Copies of the Analytical Services Request are to be glued into the field logbook. Results from the ESD counting room and from Analytical Chemistry Division are to be given immediately to the project principal investigator. 
ORNL/M-1793

\section{INTERNAL DISTRIBUTION}

1. H. L. Adair

2-11. T. L. Ashwood

12. F. P. Baxter

13. D. M. Borders

14. H. L. Boston

15. R. B. Clapp

16. T. O. Early

17. T. A. Fontaine

18. C. J. Ford

19. C. W. Francis

20. D. F. Hall

21. S. G. Hildebrand

22. D. D. Huff

23. J. M. Loar

24. C. A. Manrod

25. D. S. Marshall

26. B. C. McClelland

27. W. M. McMaster

28. L. E. McNeese

29-32. C. M. Morrissey

33. J. B. Murphy
34. C. E. Nix

35. T. F. Scanlan

36. S. H. Stow

37. D. W. Swindle

38. M. F. Tardiff

39. A. L. Thomas

40. J. R. Trabalka

41. J. E. Van Cleve

42. S. D. Van Hoesen

43. L. D. Voorhees

44. J. W. Wade

45. J. A. Watts

46. C. Whitmire, Jr.

47-50. D. S. Wickliff

51. Central Research Library

52-61. ESD Library

62-63. Laboratory Records Dept.

64. Laboratory Records, ORNL-RC

65. ORNL Patent Section

66. ORNL Y-12 Technical Library

\section{EXTERNAL DISTRIBUTION}

67. J. F. Franklin, Bloedel Professor of Ecosystem Analysis, College of Forest Resources, University of Washington, Anderson Hall (AR-10), Seattle, WA 98195

68. G. M. Hornberger, Professor, Department of Environmental Sciences, University of Virginia, Charlottesville, VA 22903

69. G. Y. Jordy, Director, Office of Program Analysis, Office of Energy Research ER-30, G-226, U.S. Department of Energy, Washington, DC 20545

70. R. H. Olsen, Vice President for Research, University of Michigan, Medical Science Building II, \#5605, 1301 East Catherine Street, Ann Arbor, MI 48109-0620

71. A. Patrinos, Acting Director, Environmental Sciences Division, Office of Health and Environmental Research, ER-74, U.S. Department of Energy, Washington, DC 20585

72. F. J. Wobber, Environmental Sciences Division, Office of Health and Environmental Research, ER-74, U.S. Department of Energy, Washington, DC 20585

73. Office of Assistant Manager for Encrgy Research and Development, U.S. Department of Energy Oak Ridge Field Office, P.O. Box 2001, Oak Ridge, TN $37831-8600$

74-83. Office of Scientific and Technical Information, P.O. Box 62, Oak Ridge, TN 37831 

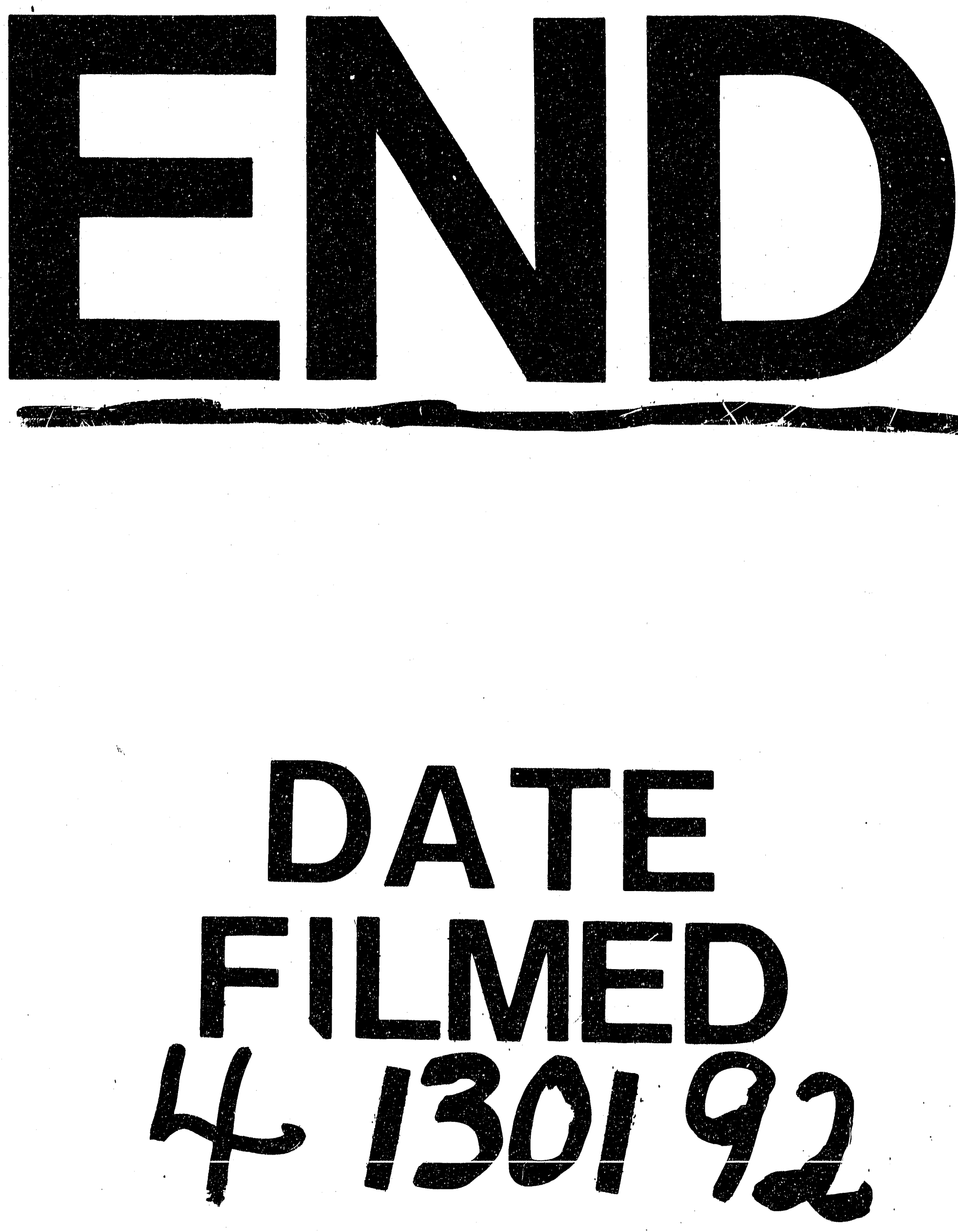
